\title{
La Pala del Moretto della Chiesa di Sant'Andrea: una traduzione 3D per la fruizione di soggetti con disabilità visiva
}

\author{
Alessio Cardaci \\ Francesco Sala
}

Abstract

La Chiesa di Sant'Andrea Apostolo in via Porta Dipinta a Bergamo è uno scrigno che conserva, nelle sue architetture e con le sue opere, un patrimonio di enorme valore storico e culturale. La conoscenza e la valorizzazione del patrimonio culturale richiede un avvicinamento pluridisciplinare in grado di integrare le capacità tecniche dell'ingegneria alla sensibilità dello studio delle scienze umanistiche e dell'arte. La comprensione della fabbrica, infatti, ha coniugato all'indagine storica, la lettura metrica, materica e dello stato di alterazione; tutto questo per trasformare la chiesa in un luogo fruibile senza barriere architettoniche e sensoriali. In particolare grazie alla realizzazione di artefatti 3D dei suoi dipinti, le opere del tempio saranno fruibili anche alle persone ipovedenti e non-vedenti. I modelli fisici, corredati da sensori che, attivati al tocco durante l'esplorazione tattile, traducono il colore in suoni consentiranno la comprensione e il godimento dell'opera anche a chi portatore di handicap.
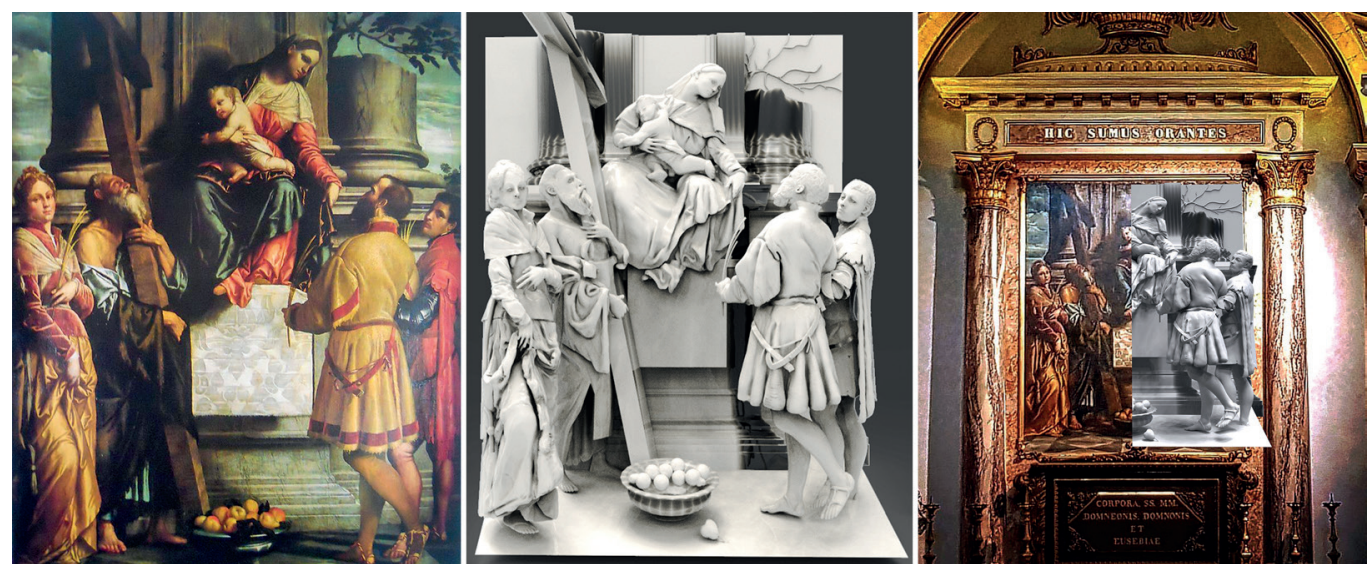


\section{Introduzione}

La Chiesa di Sant'Andrea Apostolo in via Porta Dipinta a Bergamo è uno scrigno che conserva, nelle sue architetture e con le sue opere, un patrimonio di enorme valore storico e culturale. L'attuale fabbrica neoclassica, su pianta centrale con cupola semisferica, è stata disegnata dall'architetto Ferdinando Crivelli; edificata nella metà dell'Ottocento essa sorge sull'area un tempo occupata da una basilica cimiteriale protocristiana intitolata a Sancti Andree.

II coinvolgimento dell'Università degli studi di Bergamo, al fine della conoscenza del plesso per il riuso delle sue parti ipogee (lo spazio teatrale e la sala espositiva del piccolo museo), è stata l'occasione per uno studio rivolto al godimento della chiesa da soggetti diversamente abili. Una ricerca, in collaborazione con la sezione dell'associazione $\mathrm{UICl}$ (Unione Italiana dei Ciechi e degli Ipovedenti) di Bergamo, incentrata non solo sul tema dell'abbattimento delle barriere architettoniche ma indirizzata alla realizzazione di modelli fisici, sia della fabbrica che delle opere scultoree e dei dipinti (fig. I). I modelli virtuali frutto del rilievo e della modellazione [Cardaci 2020] hanno, infatti, acquisito fisicità attraverso la stampa 3D, permettendo ai portatori di un handicap visivo di conoscere la storia del tempio, di poterne comprendere l'evoluzione costruttiva, di 'vedere' attraverso l'immaginazione e la percezione tattile le opere pittoriche in essa custodite.

La sperimentazione ha avuto inizio con la trasposizione della nota Pala di Alessandro Bonvicino detto il Moretto, una Sacra Conversazione legata alla venerazione bergamasca dei SS. Martiri Domno e i nipoti Domneone ed Eusebia [Uccelli I874], le cui reliquie sono conservate nella sagrestia. Alla ricostruzione dello spazio prospettico attraverso le regole della geometria proiettiva ha fatto seguito la modellazione 'artistica' della scena e dei personaggi che, quindi, sono stati tradotti in un modello fisico; un processo che ha visto la realizzazione di prime bozze che sono state esaminate e modificate con l'unione dei ciechi e degli ipovedenti; le loro indicazioni hanno infatti consentito di stabilire dimensioni delle linee, grandezza della copia finale, grado di dettaglio e semplificazioni per la comunicazione del dipinto. Un percorso collaborativo che ha portato alla definizione di un archetipo di riferimento per la realizzazione dei quadri tattili degli altri dipinti (la Pala di San Donnino di Francesco Bassano del I 585; la Natività di Jacopo Palma il Giovane del I 603; le tele di Alessandro Varotari, noto anche come il Padovanino, raffiguranti il Martirio di Sant'Andrea, il Coro di angeli festanti e il Coro di angeli musicanti e databili intorno al 1630.

Fig. I. La presentazione del progetto in occasione dell'evento di Public Engagement promosso dall'Università degli studi di Bergamo presso di Bergamo presso la chiesa di Sant'Andrea Apostolo.
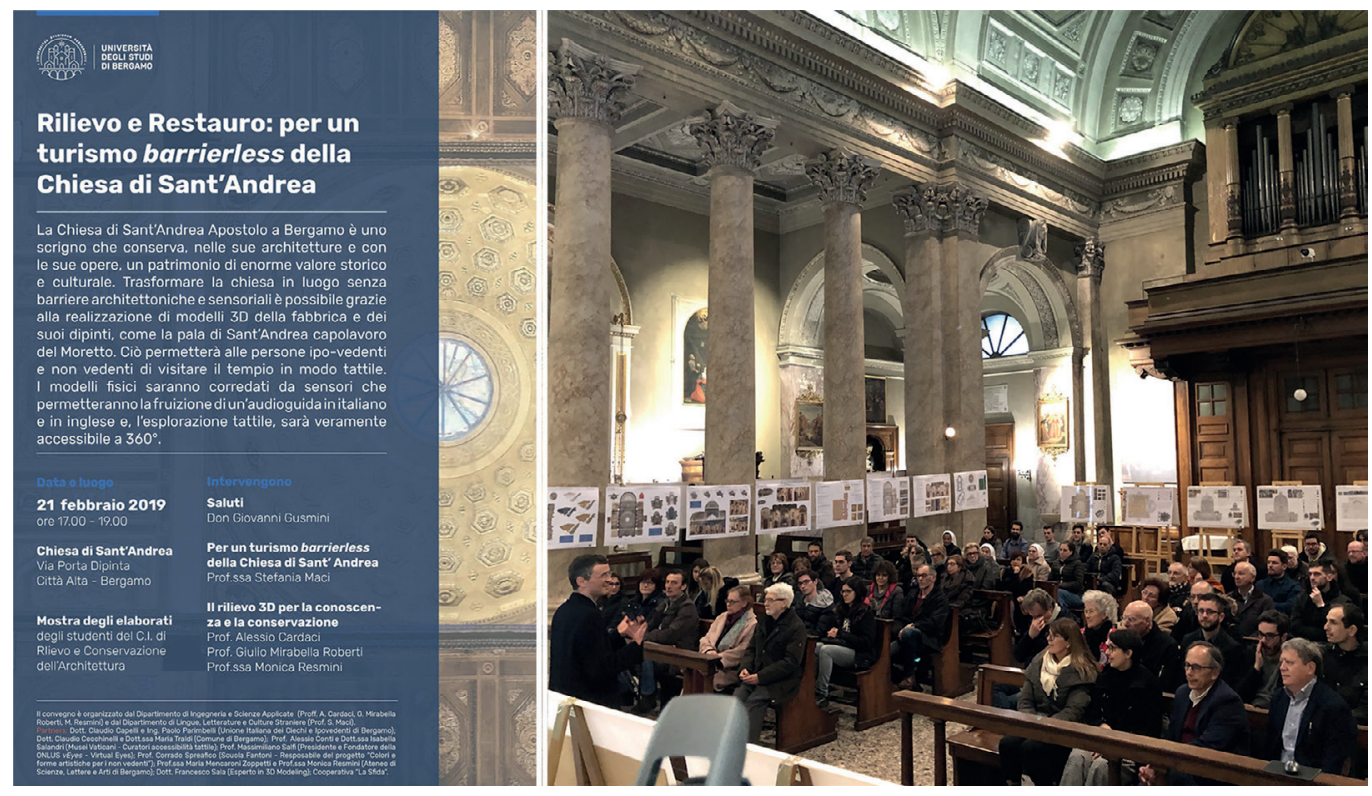


\section{La percezione di un dipinto per un sogetto ipo-vedente o non-vedente}

Il beneficio della bellezza di una raffigurazione pittorica, il godere dell'emozione che può trasmettere la visione di un dipinto è una peculiarità negata a chi è ipovedente o non-vedente. L'impiego ormai diffuso del prototyping nel campo dei beni culturali, grazie alla creazione di modelli fisici di opere pittoriche, ha concesso la comprensione di un'opera anche a chi è colpito da un handicap della vista.

II mondo delle forme può, infatti, essere sensorialmente percepito attraverso il tatto con la trasposizione a rilievo del quadro [Poscolieri 2019], in modo che si possano toccare le figure e gli oggetti rappresentati per ricostruire, con l'immaginazione, il contesto scenografico (come accade ad un normo dotato grazie alla finzione della rappresentazione prospettica). I dipinti sono, in molti casi, la proiezione su un piano di un luogo tridimensionale e la comprensione della spazialità della scena da un'immagine piana è possibile attraverso la ricomposizione percettiva operata dal nostro intelletto [Ansaldi 2018].

L'intendimento di un'opera figurativa per un disabile visivo non si può ricondurre esclusivamente al riconoscimento dei profili, ma necessita anche dell'intendimento dei colori. La sola percezione tattile, tuttavia, non è sufficiente per beneficiare dell'esperienza di un'opera; il solo toccare un quadro riprodotto in $3 \mathrm{D}$ non è in grado, infatti, di trasmette il piacere estetico e le minute informazioni possibili con il senso della vista [Levi 20 I3]. La comprensione di una tela pittorica necessita di una narrazione integrativa, stimolando il senso dell'udito, al fine di aggiungere quei contenuti qualitativi e quantitativi mancanti. Una illustrazione verbale e musicale che non sia una semplice guida audio, ma un sistema di stimoli sonori che si attivano durante l'esplorazione con la mano dell'artefatto fisico. II suono deve estendere la comprensione al fine di comunicare le diverse tinte, la luce di una scena, la rispondenza realistica di un volto, la drammaticità di un contesto.

II colore, pur essendo una caratteristica ottica, può essere ricostruito attraverso la sinestesia, cioè sfruttando la possibilità di uno stimolo percettivo di evocarne spontaneamente un altro. L'associazione sinestesica tra colore e suono è largamente usata in questo ambito [Romeo et al 20 |8]; ogni cromia è associato ad un suono la cui variazione di intensità e/o direzione consente di comunicarne le varie sfumature. Sempre più frequentemente i quadri tattili sono dotati di rilevatori di pressione, minuti sensori quasi privi di spessore che, attivati al tocco come semplici interruttori, generano delle note che associano il colore. II modello 3D ha infatti previsto dei piccoli fori, in parti opportune al fine di poterle accogliere; la parte riguardante la progettazione della stampa 3D e dei sensori esula comunque dalla trattazione di questo saggio ricadendo in ambiti disciplinari estranei alle competenze degli autori.

II rilievo scultoreo è stato comunque immaginato per comunicare, anche in assenza del suono, l'universo raffigurato nel quadro come se appartenesse al mondo reale; chiaroscuri e colori sono quindi stati convertiti in volumi (e non semplici sagome piatte) al fine di lasciare alla percezione tattile la scoperta della narrazione del dipinto. Il modello fisico ha reso reale la rappresentazione attraverso la ricostruzione 'artistica', quindi, non basata sul rigido rigore delle regole della prospettiva [Bellini 2000; Rizzi 200 I] e in ragione della capacità di lettura e di comprensione delle persone ipovedenti e non vedenti.

\section{L'interpretazione del quadro e la sua costruzione spaziale}

La Pala del Moretto, realizzata tra il I536 e il I537, ritrae la Madonna adorata dai santi e con in braccio Gesù Cristo; in primo piano, a destra Eusebia e Andrea con un grande crocifisso, a sinistra Domno e Domneone con la palma del martirio (fig. 2). Un impianto scenico caratterizzato da un 'non finito' contraddistinto da un basamento con modanature, in parte coperto da un drappo con decorazioni vegetali, che sostiene una grande lesena e due colonne; quella di destra è tronca e in stato di rovina, con dietro il ramo di una pianta e poche foglie. II sistema architettonico rappresenta il trono su cui è seduta Maria; la sua volumetria marcata dall'illuminazione proveniente dal basso si contrappone allo sfondo 'appiattito ed uniforme' - come se dipinto su di un fondale teatrale - raffigurante una collina alberata sotto un cielo nuvoloso [Rodeschini I $98 \mathrm{I}$ ]. 


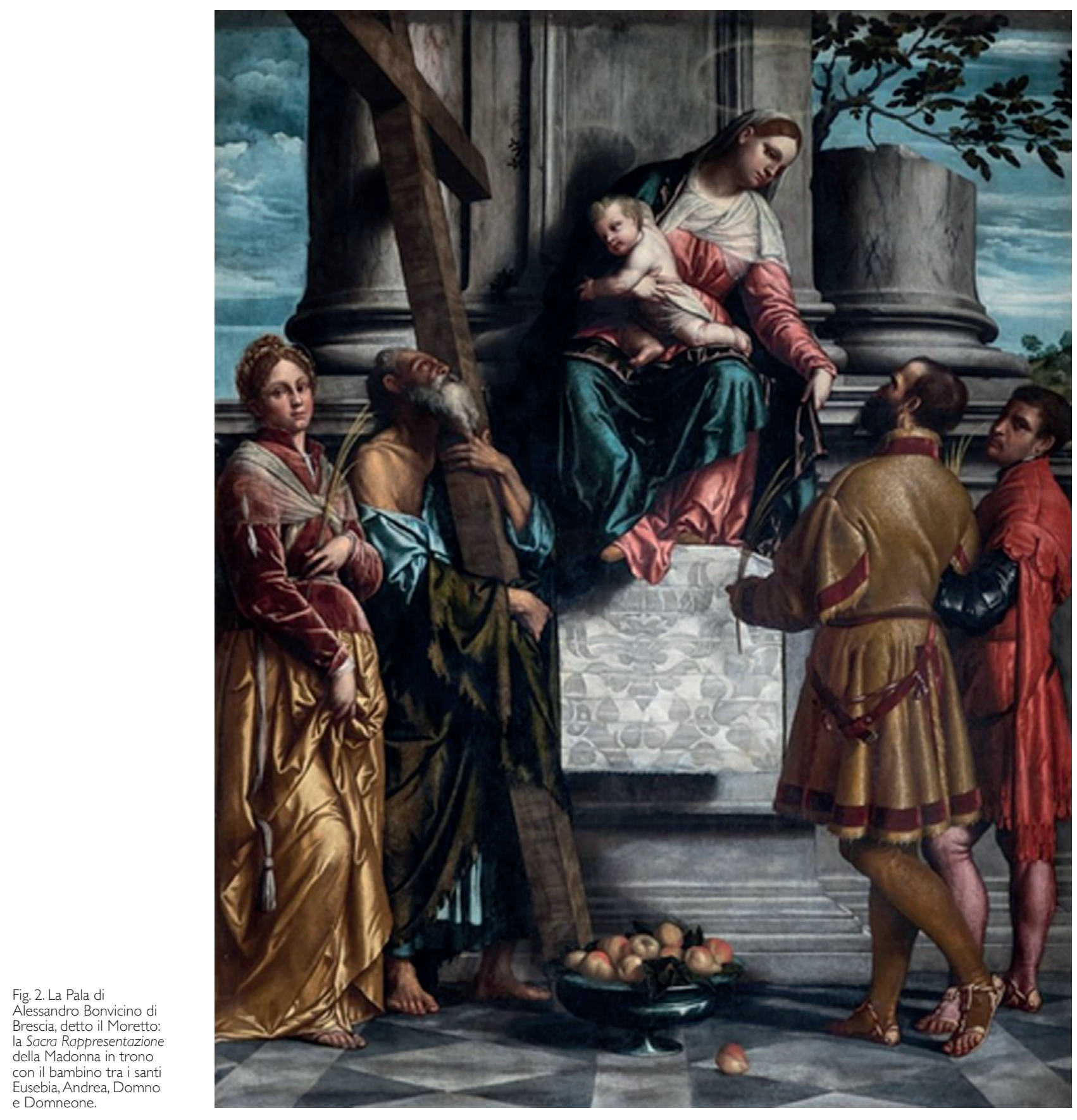

La proiezione conica è una rigorosa prospettiva centrale con il punto principale posto al centro del drappo. II decoro geometrico della pavimentazione permette di ricostruire la geometria della scena nonché di risalire alla profondità del basamento anche se coperto, in parte, dalle figure di primo piano, con i santi disposti in favore della linea di proscenio, e la Madonna con il Bambino sollevata, come posta sopra una mechanè, al di sopra degli altri personaggi.

La Sacra Conversazione pur seguendo l'eredità rinascimentale presenta alcuni elementi manieristici, come la fruttiera con delle pere la cui funzione è di esaltare la lettura prospettica e indirizzare l'attenzione verso il punto principale o, ancora, la rottura della quarta parete tramite gli sguardi rivolti verso l'esterno della scena di Eusebia e di Domneone; la posa rigida e formale dei personaggi all'interno della griglia teatrale, infatti, si contrappone all'atteggia- 
mento informale dei due santi che si rivolgono direttamente all'osservatore. È possibile riconoscere due tipi di relazioni all'interno del quadro: una diegetica, che intercorre tra Andrea, Domno e la Madonna, ed una extra-diegetica, che coinvolge direttamente lo spettatore attraverso gli occhi degli altri protagonisti (fig. 3).

Uno stratagemma realistico della tradizione pittorica rinascimentale e finalizzato al coinvolgimento dello spettatore alla vicenda. II Moretto ripensa così lo spazio, in funzione dell'azione degli attori adeguando alle loro intenzioni la gabbia scenica e "I'architettura quasi si nasconde dietro la grandezza delle figure" [Gombosi 1943, p. 47]. I santi hanno dinamicità grazie alla propria gestualità contrapponendosi alla "Madonna e ancor più al Bambino che dimostrano maggiore compostezza e adesione allo spazio razionale" [Gombosi 1943 p. 50]. II Cristo infatti è disegnato inclinato sulla sinistra in modo speculare a Maria, determinando così una forma $\mathrm{a} \mathrm{V}$ le cui linee di tensione fanno confluire lo sguardo su un secondo punto di fuga decentrato, posto sulla linea d'orizzonte dietro a san Domno [Boselli 1954].

Fig. 3. Analisi delle relazioni dei personaggi allinterno della rappresentazione al fine di restituire gli atteggiamenti corporei $e$ le espressioni dei volti.

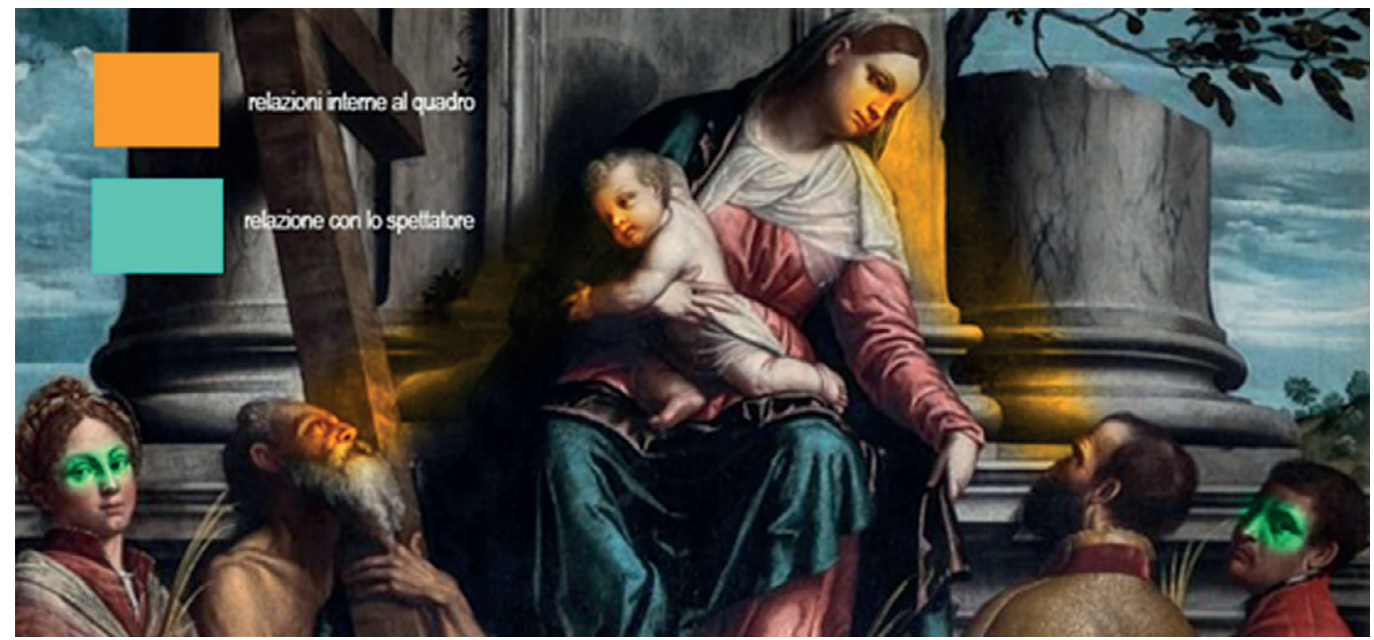

La traduzione del dipinto in un modello $3 \mathrm{~d}$

L'elaborazione del modello 3D è stato il frutto di un processo di traduzione della forma pittorica in volumi digitali a tutto tondo, poi risolti in un altorilievo. Uno sviluppo progettuale organizzato sulle esigenze e sulla percettibilità dei fruitori (grazie alla collaborazione con UICl di Bergamo) e preceduto dalla realizzazione di primi prototipi fisici che sono stati migliorati a seguito della verifica tattile degli utenti con disabilità visiva. Questo ha permesso di inquadrare non solo cosa venisse effettivamente riconosciuto dalla persona ipovedente o non-vedente, ma anche in che misura il contenuto della rappresentazione potesse essere descritto attraverso la modellazione e la stampa.

L'obbiettivo finale ha quindi fortemente condizionato la costruzione del modello, non rendendolo semplicemente un esercizio di forma finalizzato ad una valutazione estetica, ma un rilievo scultoreo anche apprezzabile alla vista.

I personaggi e gli oggetti rappresentati sul quadro sono stati scomposti in elementi isolati e restituiti nella loro tridimensionalità, per quindi essere ricollocati all'interno dello spazio scenico. La divisione in parti del dipinto è stata fatta secondo gruppi coerenti di attori ed architetture, nonché includendo gli attributi di santità e gli oggetti più piccoli. La Pala è stata disunita in dieci sottoinsiemi: il fondale con le nuvole e la collina, la pianta; il basamento con colonne e lesena, la pavimentazione; la fruttiera e, ovviamente, le figure dei santi e la Madonna col Bambino (fig. 4).

La modellazione è stata eseguita con l'uso integrato di più software sia di grafica 2D (Adobe ${ }^{\circledR}$ Photoshop e Adobe ${ }^{\circledR}$ Illustrator) per scontornare le silhouettes e completarle laddove 

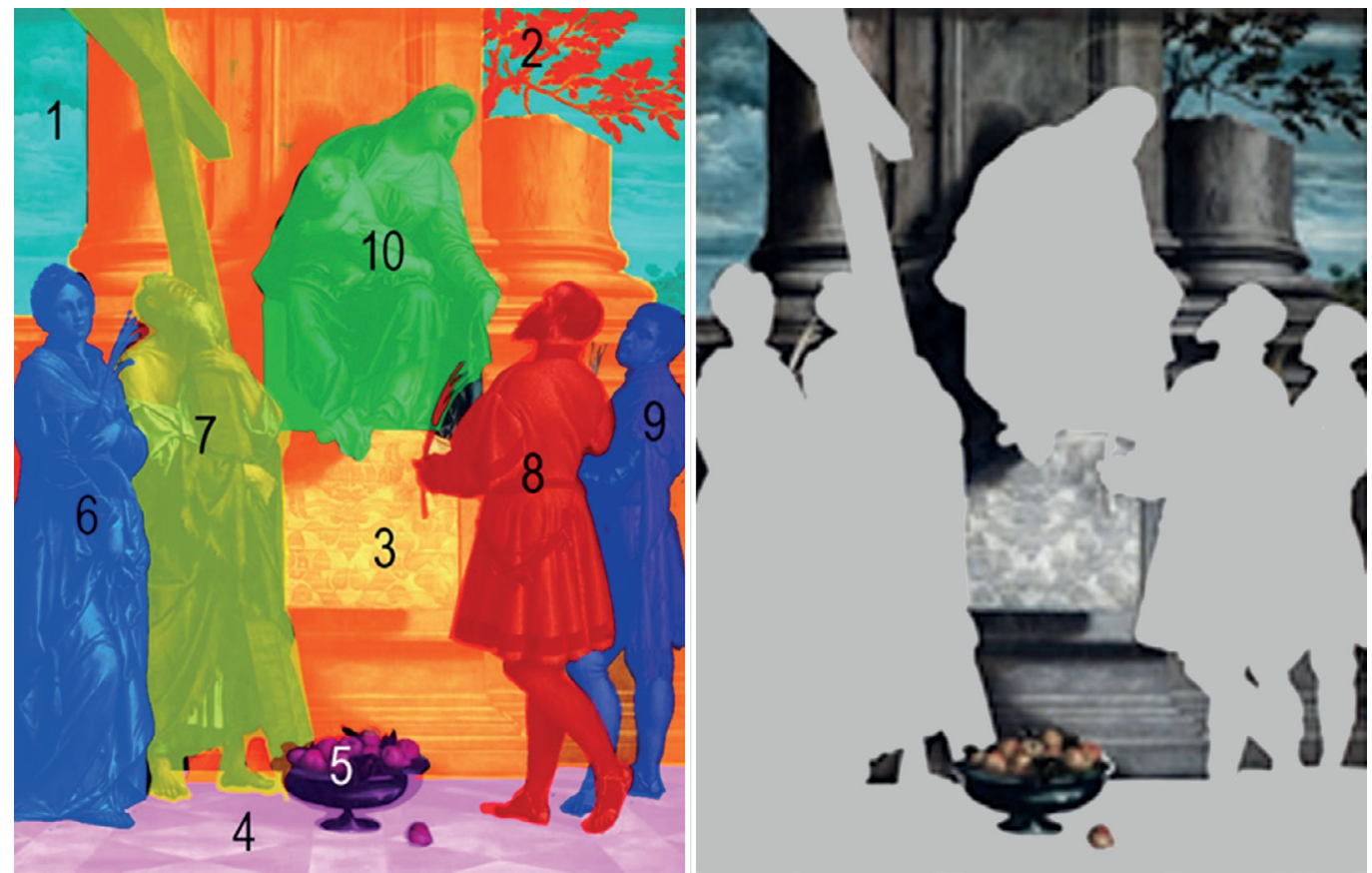

nascoste e/o incomplete, sia di modellazione per renderli volumi virtuali (Autodesk® 3D Studio Max, Pixologic® Zbrush). La traduzione delle architetture si è basata sulle regole della prospettiva, quella dei personaggi ha seguito una prassi più 'artistica' al fine del rispetto delle proporzioni corporee e della restituzione delle espressioni dei volti (fig. 5).

II calco digitale dello sfondo non ha riprodotto le nuvole e la collina alberata a causa del minuto dettaglio che avrebbe reso dei solchi molto fitti per essere intesi con il tatto; il fondale
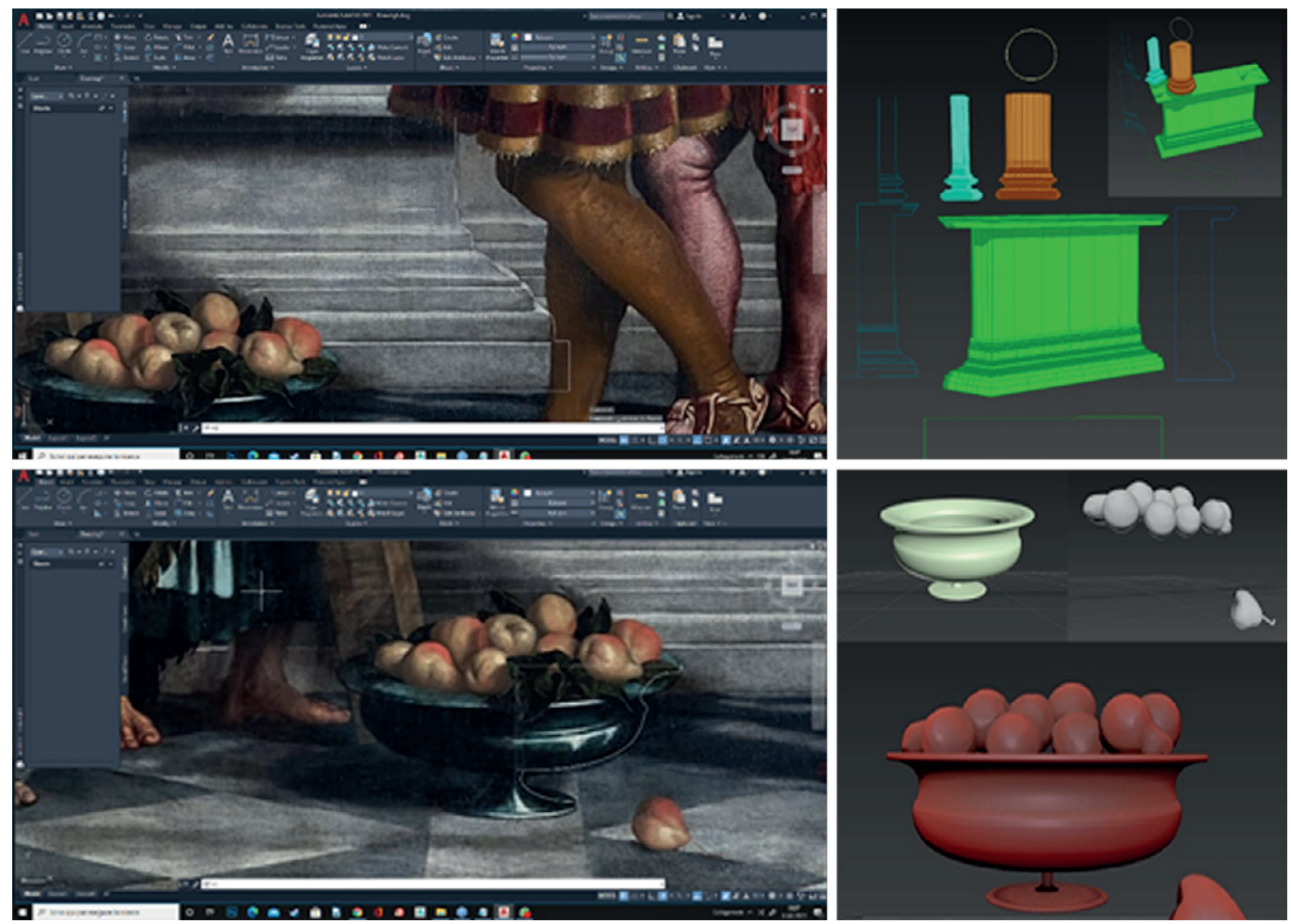


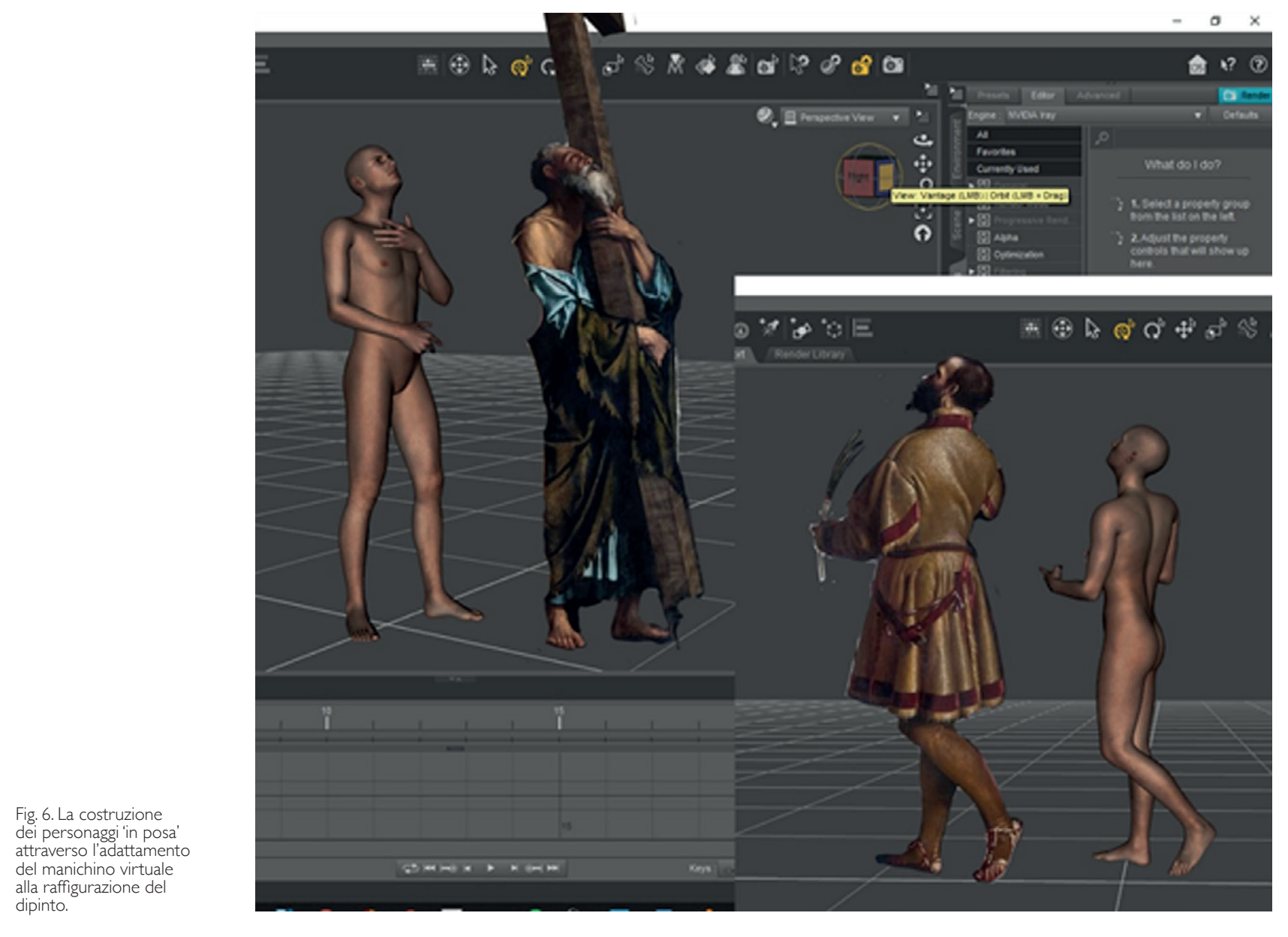

è stato sostituito da un semplice piano levigato, lasciando all'integrazione sonora l'approfondimento descrittivo dei contenuti. La stessa scelta è stata fatta per la pavimentazione perché il disegno geometrico avrebbe distratto l'attenzione dai personaggi di primo piano; i test condotti con I'UICl hanno infatti evidenziato come il motivo decorativo, fondamentale alla vista al fine della lettura della profondità della scena, non è invece in grado di comunicare il senso della spazialità a persone ipovedenti o non vedenti.

La modellazione dei personaggi ha richiesto un approccio differente perché è stato necessario concentrarsi sulla loro espressività, al fine della comunicazione del rapporto gerarchico, sociale ed emozionale in essere tra gli interpreti. La comprensione delle interazioni tra gli attori, mediante il riconoscimento di sguardi e delle pose, è stata funzionale alla narrazione. Tale aspetto è una delle prerogative della rappresentazione visuale, ma risulta però effimero all'interno nella lettura mediante il tatto. Per questo, si è cercato di usare, nella progettazione virtuale, una scala dimensionale che potesse permettere durante il gesto della lettura tattile, il sentire contemporaneamente due o più soggetti.

Questo è stato ottenuto attraverso un iter progettuale che, per ogni personaggio, è stato suddiviso in tre fasi differenti e sequenziali: la creazione della posa (con il posizionamento di un manichino virtuale senza connotati fisionomici), la caratterizzazione (attraverso l'espressione del volto e la vestizione con abiti e accessori), la deformazione antropomorfica al fine di accentuare la percezione tattile degli elementi più significati (fig. 6).

Le movenze dei personaggi sono state possibili grazie al software Daz3D® Daz Studio perché offre un vasto campionario di manichini virtuali che è possibile atteggiare attraverso il movimento della testa, del tronco e degli arti in posture che simulano il corpo umano. La vestizione è però avvenuta con una modellazione poligonale in Autodesk® 3D Studio Max, poi rifinita in Pixologic $®$ Zbrush. Una prassi complessa e, per così dire, 'artigianale' che ha 
Fig. 7. La caratterizzazione dei personaggi con la modellazione delle espressioni del volto e la vestizione con abiti accesson.

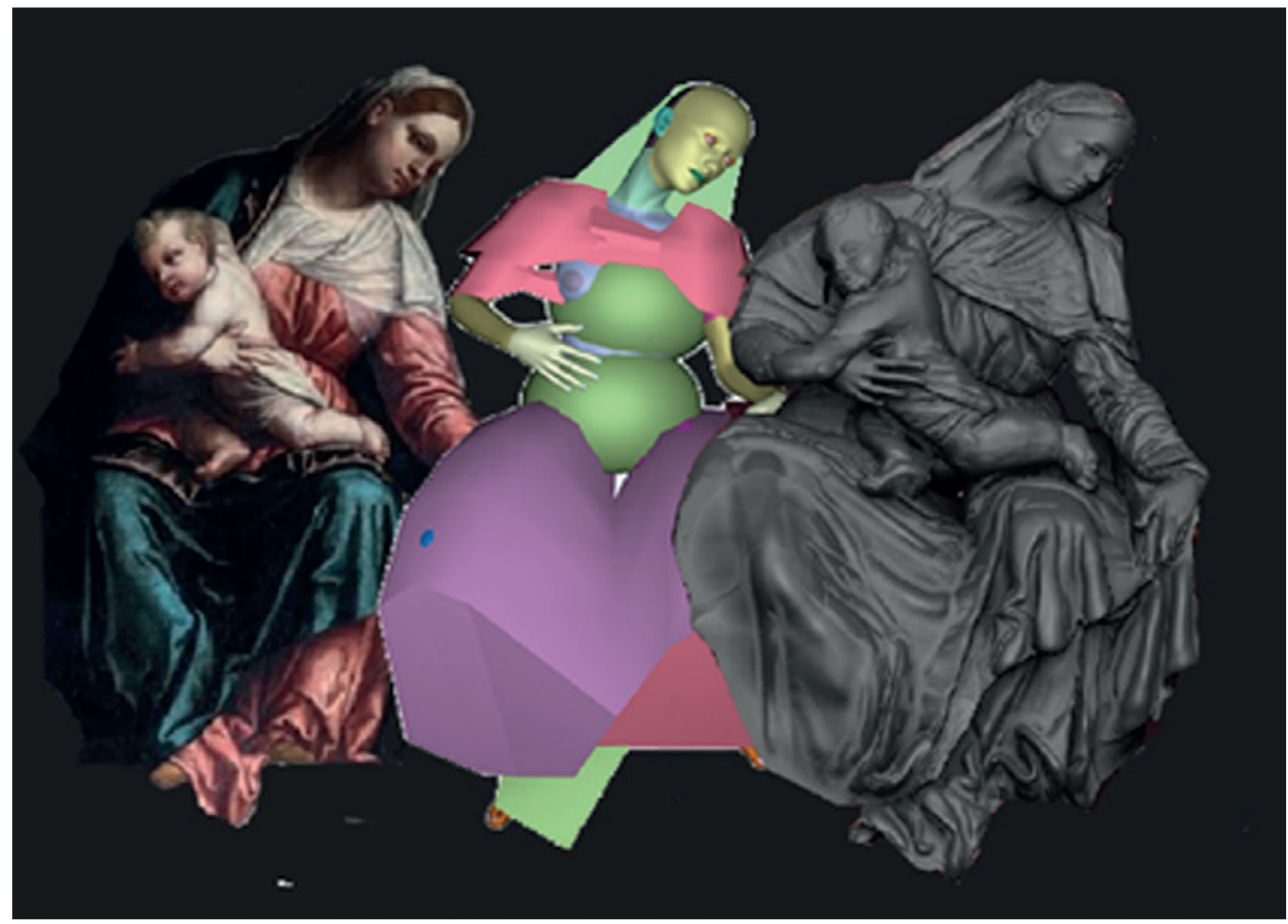

permesso una maggior realismo nella definizione dei panneggi. Per rendere il vestito coerente, dunque, con la raffigurazione pittorica è stato necessario fonderlo al manichino in modo tale che, attraverso la modellazione libera, potesse essere adattato come un unico oggetto (fig. 7). Una scelta necessaria perché la resa realistica sui corpi espressa con pieghe, intrecci e effetti legati alla fisica non è in grado di riflettere il realismo interno di un dipinto; la dinamica fisica non può tradurre quella artistica, sviluppata come linguaggio e dunque attraverso un certo livello di astrazione (fig. 8).

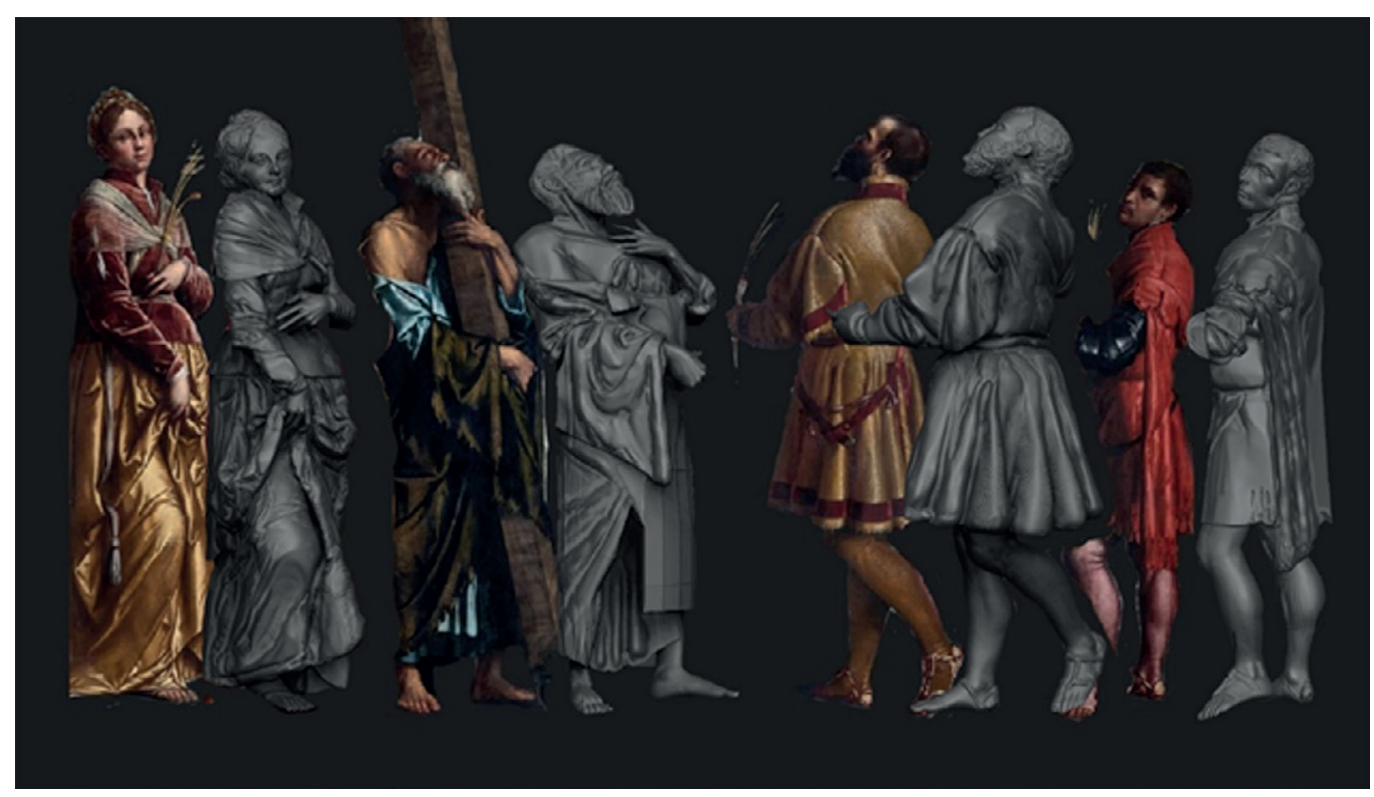


Fig. 9. Lo studio della profondità dell'altorilievo: esempi con diversi gradi di intensità (alto medio molto basso).

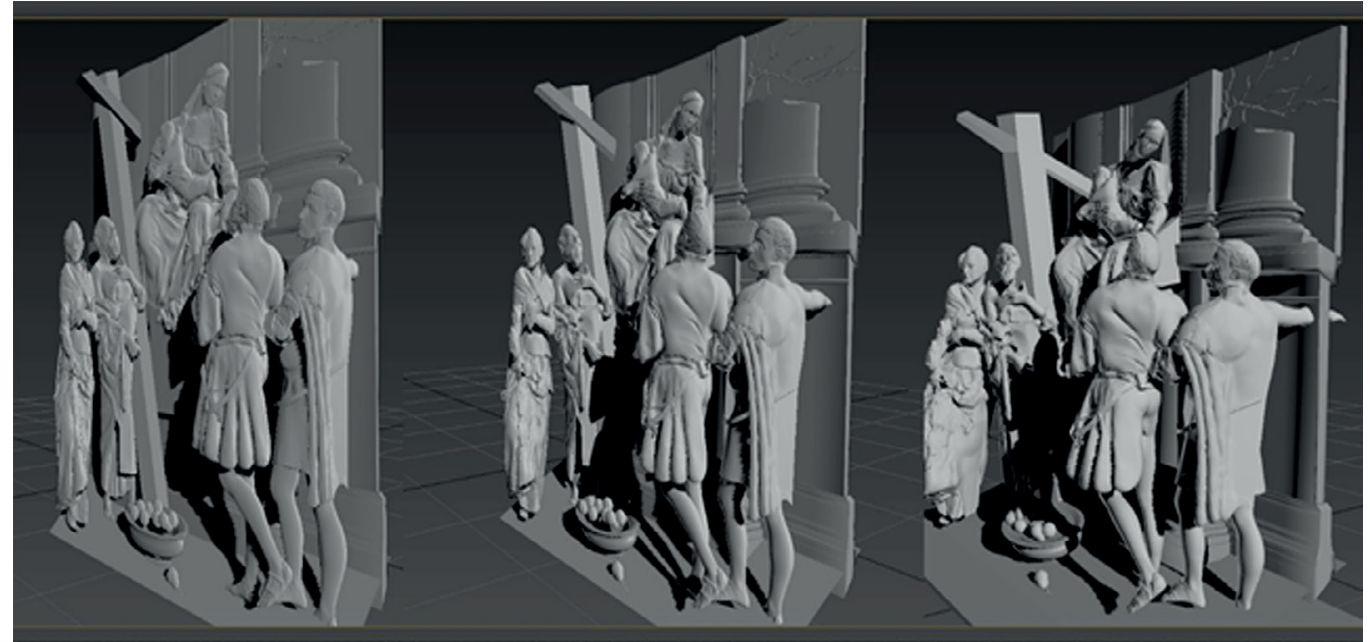

\section{L'altorilievo virtuale e la sua stampa 3D}

La traduzione fisica del dipinto ha richiesto di riadattare l'immagine ai dettami dell'arte scultorea; un'analisi critica alla ricerca del giusto rapporto tra la veritiera corrispondenza della struttura geometrico-spaziale della rappresentazione, l'obbligatoria stilizzazione della forma (anche in ragione delle possibilità tecniche della stampa tridimensionale), le esigenze di intendimento dei soggetti ipo-vedendi e/o non-vedenti [Riavis 2020].

La gabbia spaziale è stata immaginata come la materializzazione dell'immagine prospettica, con gli attori e gli oggetti posizionati e distanziati tra loro; una configurazione difficilmente leggibile da chi portatore di un handicap visivo perché, interrompendo la continuità tattile, non permette di intuire le relazioni tra le varie parti del dipinto. Di contro gli autori hanno abbandonato la tradizionale strada dell'estrema semplificazione dei contenuti in semplici profili in rilievo, comune a varie esperienze museali [Tiberti 2020], che avrebbe causato la perdita della ricchezza della scena e resa vana l'attività di ricerca.

L'espressione artistica dell'altorilievo è apparsa la scelta più adeguata perché in grado di conservare le caratteristiche del disegno a rilievo senza rinunciare alla ricchezza dei particolari; si è sperimentato un accorciamento della profondità e l'inclinazione del piano pavimentale e delle quinte, mantenendo comunque distaccate le figure sovrapposte ed evidenziando la suddivisione tra i diversi panneggi. Una ricreazione tattile della finzione prospettica che ha consentito di svelare l'illusione della distanza, fondata su di un sistema di percezione legato alla vista, dichiarandolo al tatto come se lo spazio subisse una riduzione di scala non uniforme e limitata alla sola direzione ortogonale al quadro (fig. 9).

Una soluzione che ha dato risposta alla questione del rispetto del significato dell'opera d'arte che, pur con la costrizione degli elementi della composizione forzanti all'interno di una griglia più stretta, hanno continuato ad esprime l'originalità della scena e l'idea delle interazioni degli attori. Opportunità non concessa con il semplice disegno schematico a rilievo, in grado di consentire ai portatori di un handicap visivo di ricostruire mentalmente le relazioni, e godere dei volumi e i contrasti di ombre e luci trasposti in distanze e profondità. (fig. 10).

\section{Conclusione}

Il progetto è stato un pragmatico esperimento di materializzazione delle componenti formali e significative di un'opera pittorica; attraverso la trascrizione in altorilievo si è, da un lato mantenuta la particolarità espressiva connessa all'uso del colore e del chiaroscuro, dall'altro svelata la costruzione illusoria della prospettiva nonché avviata una riflessione sul legame tra 
l'immagine e la resa plastica. L'abbandono del colore perché imperscrutabile ad un pubblico di persone ipovedenti e non vedenti, ha determinato la creazione non di una copia ma di un'opera scultorea singolare ed unica, autonoma e indipendente dall'originale.

La traduzione operata non ha infatti utilizzato lo stesso linguaggio della pittura ma una semiotica totalmente diversa; la ragione di fruizione attraverso cui è stato sviluppato il modello lo ha differenziato dall'originale, renderlo un complemento che ne incrementa il suo significato artistico e che può essere fruito anche da chi ha l'incredibile dono della vista.

Fig. 10. II modello conclusivo in

un'immagine render con ChaosGroup $\otimes_{\text {Vray }}$ prodotta all'interno del software di modellazione Autodesk@ 3D Studio Max.

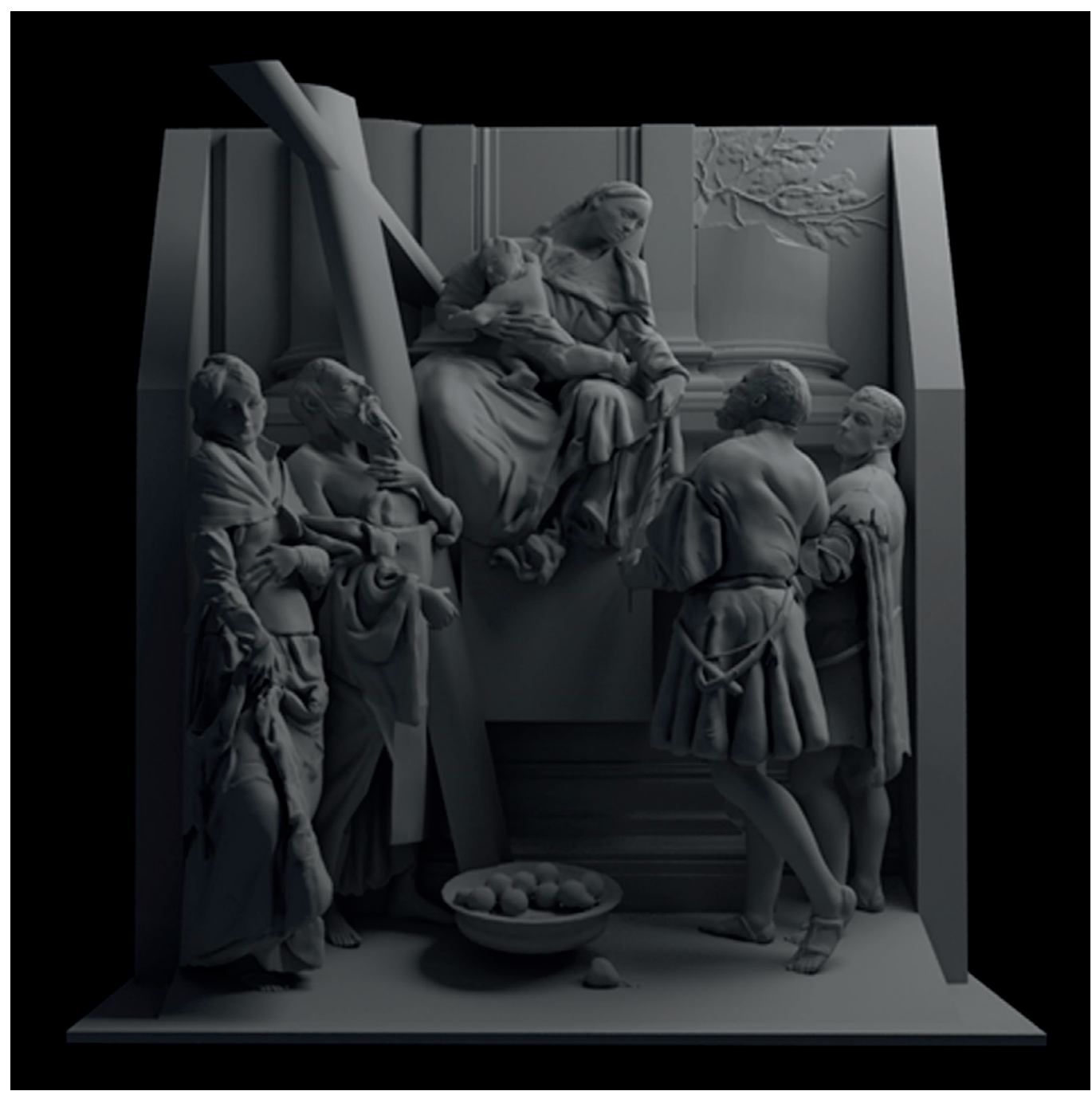

Crediti

L'attività di ricerca è stata condotta sinergicamente dagli autori che hanno condiviso obiettivi, metodologie e risultati. La responsabilità redazionale risulta equamente così suddivisa: Alessio Cardaci (introduzione, primo paragrafo e conclusione), Francesco Sala (secondo, terzo e quarto paragrafo).

\section{Riferimenti bibliografici}

Ansaldi B. (2018). Perspective and the Blind: towards a communication of painted spaces to the visually impaired. In ICGG 2018 - Proceedings of the $18^{\text {th }}$ International Conference on Geometry and Graphics. Cham: Springer International, pp. 54I-552.

Bellini A. (2000). Toccare l'arte: l'educazione estetica di ipovedenti e non vedenti. Roma: Armando Editore.

Boselli C. ( 1954). II Moretto: I 498- I 554. In Commentari dell'Ateneo di Brescia per l'anno 1954 (Supplemento). Pubblicazione commemorativa nel quarto centenario della morte del Moretto. Brescia:Tipografia Fratelli Geroldi. <https://www.ateneo.brescia. it/controlpanel/uploads/supplementi-ai-commentari/S-1954a\%20Boselli\%20Moretto.pdf> (consultato il I0 maggio 202 I). 
Cardaci A. (2019). La Chiesa di Sant'Andrea in via Porta Dipinta a Bergamo: dallo studio critico degli antichi disegni al rilievo per la conoscenza della fabbrica. In $41^{\circ}$ convegno internazionale dei docenti delle discipline della rappresentazione. Congresso della unione italiana per il disegno. Roma: Gangemi Editore, pp. 509-5 I6.

Gombosi G. (1943). II Moretto da Brescia. Basilea: Holbein-Verlag.

Levi F. (20 I 3). L'accessibilità alla cultura per i disabili visivi: storia e orientamenti. Torino: Zamorani.

Poscolieri M. (2019). La percezione della pittura: oltre le barriere visive. In Baroni S. Bertini F. (a cura di). Tradurre la pittura: incisioni e quadri tattili (Giornata di studi, Roma, 3 dicembre 2019), pp. 299-317. Roma: Universitalia, .

Riavis V. (2020). La Chiesa di Sant'Ignazio a Gorizia tra architettura e pittura: analisi geometrica e restituzioni per la rappresentazione tattile. Trieste: EUT Edizioni Università di Trieste. <https://www.openstarts.units.it/handle/I0077/3 I055> (consultato il I0 maggio 2021)

Rizzi E. (200 I). Percezione e linguaggio: problemi critici. Firenze: Cadmo Editore.

Rodeschini M. C. (198I). Note sulle due pale del Moretto a Bergamo. In AA.VV. Notizie da Palazzo Albani: rivista annuale di storia e teoria delle arti. ( $10-2)$. Urbino: Edizioni QuattroVenti.

Romeo K. et al. (20 I8). Simplification of Painting Images for Tactile Perception by Visually Impaired Persons. In: Miesenberger K., Kouroupetroglou G. (Eds.). Computers Helping People with Special Needs. ICCHP 20 I8. Lecture Notes in Computer Science, vol. 10897. Cham: Springer.

Tiberti V. (2020). Il museo sensoriale: l'accessibilità culturale e l'educazione artistica ed estetica per le persone con minorazione visiva nei musei del comune di Roma. Roma: Sapienza Università Editrice.

Uccelli P.A. (1874). Dei santi martiri Domno Domnione ed Eusebia venerati nella Chiesa prepositurale di Sant'Andrea in Bergamo: Commentario. Bergamo:Tipografia Pagnoncelli.

\section{Autori}

Alessio Cardaci, Università di Bergamo, falessio.cardaci@unibg.it

Francesco Sala, Università di Bergamo, f.sala22@studenti.unibg.it

Per citare questo capitolo: Cardaci Alessio, Sala Francesco (2021). La Pala del Moretto della Chiesa di Sant'Andrea: una traduzione 3D per la fruizione di sogretti con disabilità visiva/The Pala del Moretto of the Church of Sant'Andrea: a 3DTranslation for People with Visual Disabilities. In Arena A Arena M Mediati D Raffa P. (a Cura di) Connettere Un disegno per annodare e tessere Lingugogi Distanze Tecnologie Atti del $42^{\circ}$ Convegno Internazionale dei Docenti delle Discipline della Rappresentazione/Connecting. Drawing for weaving relationship. Languages Distances Technologies. Proceedings of the 42th International Conference of Representation Disciplines Teachers. Milano: FrancoAngeli, pp. 2151 - 2172 


\title{
The Pala del Moretto of the Church of Sant'Andrea: a 3D Translation for People with Visual Disabilities
}

\author{
Alessio Cardaci \\ Francesco Sala
}

Abstract

The Church of Sant'Andrea Apostolo in via Porta Dipinta in Bergamo is a treasure chest that preserves, in its architecture and with its works, a heritage of enormous historical and cultural value. The knowledge and appreciation of cultural heritage requires a multidisciplinary approach to integrate the technical skills of engineering with the sensitivity of the study of the humanities and art. The understanding of the factory has combined historical investigation, metric, material and state of alteration reading; all this to transform the church into a place that can be used without architectural and sensory barriers. In particular thanks to the realization of 3D artifacts of his paintings, the works of the temple will also be used for visually impaired and blind people. The physical models, equipped with sensors that, activated with the touch during tactile exploration, translate colour into sounds will allow the understanding and enjoyment of the work even for those with disabilities.

Keywords

3D model, drawing, perspective, art, painting
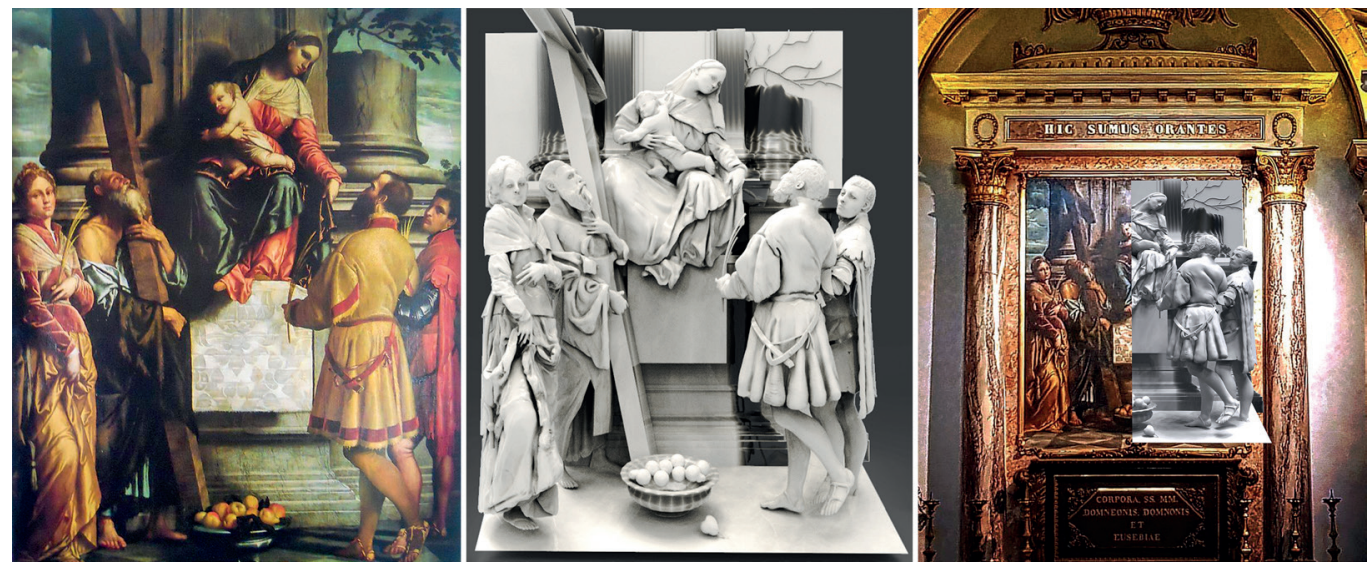


\section{Introduction}

The Church of Sant'Andrea Apostolo in via Porta Dipinta in Bergamo is a treasure chest that preserves, in its architecture and with its works, a heritage of enormous historical and cultural value.

The current neoclassical factory, on a central plan with a hemispherical dome, was designed by the architect Ferdinando Crivelli; built in the mid-nineteenth century, it stands on the area once occupied by a proto-Christian cemetery basilica named after Sancti Andree.

The involvement of the University of Bergamo, to know the complex for the reuse of its hypogea parts (the theatrical space and the exhibition hall of the small museum), was the occasion for a study aimed at the enjoyment of the church by subjects with disabilities. Research, in collaboration with the section of the $\mathrm{UICl}$ association (Italian Union of the Blind and Visually impaired) of Bergamo, focused not only on the theme of the removal of architectural barriers, but aimed at the realization of physical models, both in the factory and the sculptural works and paintings (fig. I). The virtual models resulting from the relief and modelling [Cardaci 2020] have, in fact, acquired physicality through 3D printing, allowing those with a visual handicap to know the history of the temple, to understand its constructive evolution, to 'see' through imagination and tactile perception the pictorial works kept at it.

The experience began with the transposition of the famous Pala by Alessandro Bonvicino called the Moretto, a Sacred Conversation linked to the Bergamo veneration of the SS. Martiri Domno and his nephews Domneone and Euseba [Uccelli 1874], whose relics remain in the sacristy. The reconstruction of perspective space through the rules of projective geometry was followed by the 'art' modelling of the scene and the characters that, therefore, were translated into a physical model; a process that saw the realization of first drafts that were examined and modified with the union of the blind and the visually impaired; their indications have in fact made it possible to establish the size of the lines, the size of the final copy, the degree of detail and simplifications for the communication of the painting. A collaborative path that led to the definition of a reference archetype for the realization of tactile paintings of the other paintings (the Pala di San Donnino_by Francesco Bassano (1585); the Natività of Jacopo Palma il giovane ( 603 ); the canvases by Alessandro Varotari, also known as the Padovanino, depicting the Martirio di Sant'Andrea, the Coro di Angeli festanti and the Coro di Angeli musicanti, all dating back to around 1630.
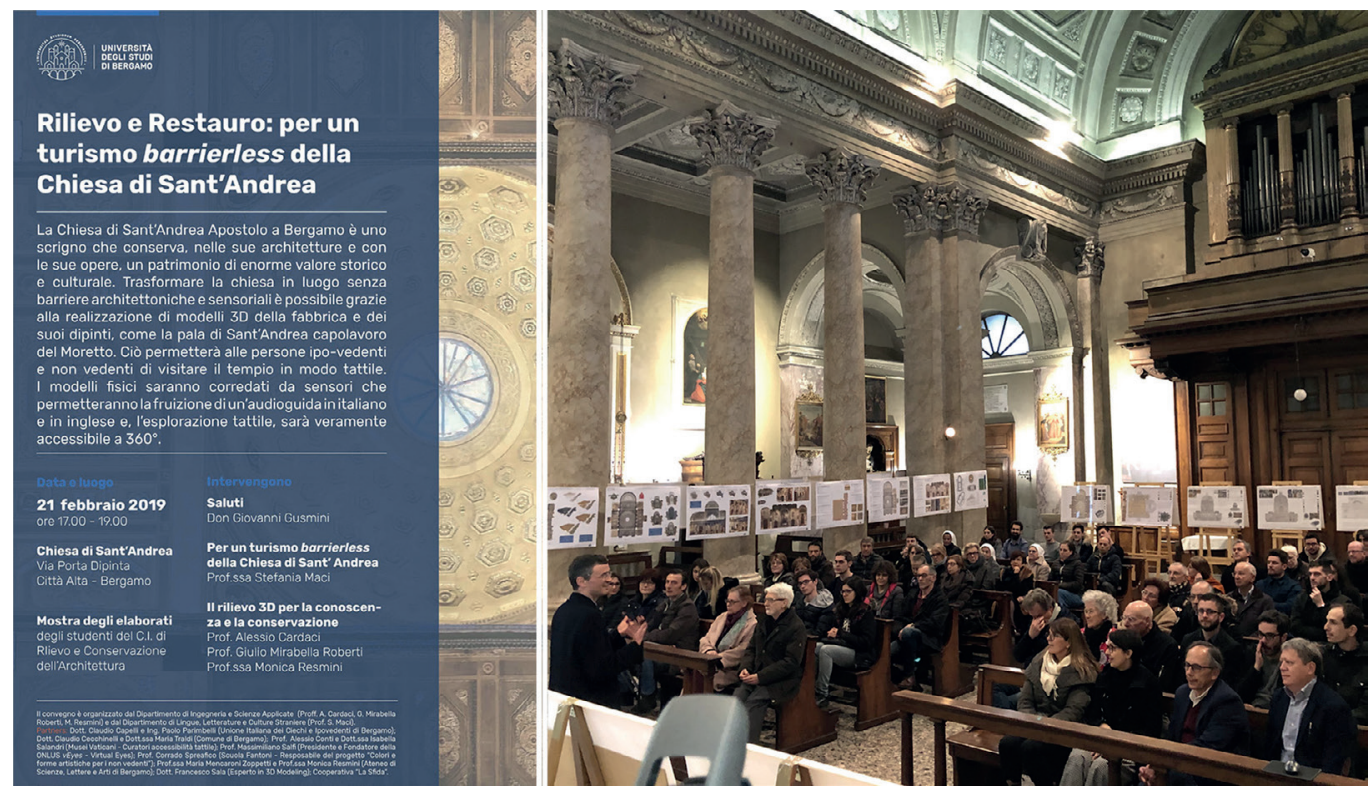


\section{Perception of a picture for a person with vision loss or blindness}

The benefit of the beauty of a pictorial representation, the enjoyment of the emotion that can transmit the vision of a painting is a peculiarity denied to those who are visually impaired or blind. The widespread use of prototyping in the field of cultural heritage, thanks to the creation of physical models of pictorial works, has granted the understanding of work even to those affected by a visual impairment.

The world of forms can, in fact, be sensory perceived through touch with the relief transposition of the painting [Poscolieri 2019], so that you can touch the figures and objects represented to reconstruct, with imagination, the scenographic context (as happens to a normal endowed thanks to the fiction of perspective representation). The paintings are, in many cases, the projection on a plane of a three-dimensional place and the understanding of the spatiality of the scene from a flat image is possible through the perceptual recomposition carried out by our intellect [Ansaldi 2018].

The intent of a figurative work for a person with a visual disability cannot be attributed solely to the recognition of profiles, but also requires the design of colours. Tactile perception alone, however, is not enough to benefit from the experience of work; just touching a painting reproduced in $3 \mathrm{D}$ is not able, in fact, to transmit the aesthetic pleasure and the minute information possible with the sense of sight [Levi 20I3]. The understanding of a pictorial canvas needs an integrative narration, stimulating the sense of hearing, to add the missing qualitative and quantitative contents. A verbal and musical illustration that is not a mere audio guide, but a system of sound stimuli that are activated during the hand scan of the physical artefact. The sound must expand the comprehension to communicate the different times, the light of a scene, the realistic responsiveness of a face, the drama of a context.

The colour, while being an optical characteristic, can be reconstructed by synesthesia, that is to say by exploiting the possibility of a perceptual stimulus to spontaneously evoke another. The synesthetic association between colour and sound is widely used in this field [Romeo et al. 20 I8]; each colour is associated with a sound whose variation in intensity and/or direction allows to communicate the various nuances. More and more often, tactile panels are equipped with pressure detectors, minutes of thickness sensors which, activated by touch as simple switches, generate notes that associate colour.The 3D model has provided for small holes, inappropriate parts to accommodate them; the part concerning the design of 3D printing and sensors is however outside the treatment of this essay falling into disciplinary areas unrelated to the competencies of the authors.

The sculptural relief was, however imagined to communicate, even in the absence of sound, the universe depicted in the painting as if it belonged to the real world; chiaroscuro and colours have therefore been converted into volumes (and not simple flat silhouettes) to leave the discovery of the narrative of the painting to tactile perception. The physical model made the representation real through 'artistic' reconstruction, therefore, not based on the rigid rigor of the rules of perspective [Bellini 2000; Rizzi 200 I] and because of the ability of visually impaired and blind people to read and understand.

\section{The interpretation of the painting and its spatial construction}

The Pala of Moretto, built between 1536 and I537, depicts our Lady adored by the saints and holding Jesus Christ; in the foreground, on the right Eusebia and Andrea with a large crucifix, on the left Domno and Domneone with the palm of martyrdom (fig. 2). A staging system characterized by a 'un finished' characterized by a plinth with mouldings, partly covered by a drape with vegetable decorations, which supports a large lesena and two columns; the one on the right is truncated and in a state of ruin, with behind the branch of a plant and a few leaves. The architectural system represents the throne on which Mary is seated; its volume marked by the illumination coming from below contrasts with the 'flattened and uniform' background backdrop -as if painted on a theatrical backdrop backdrop- depicting a tree-lined hill under a cloudy sky [Rodeschini 198I]. 
Fig. 2. The Pala by Alessandro Bonvicino of Brescia, known as Representation of the Madonna with the child among the saints Eusebia, Andreathe saints Eusebir Domneone.

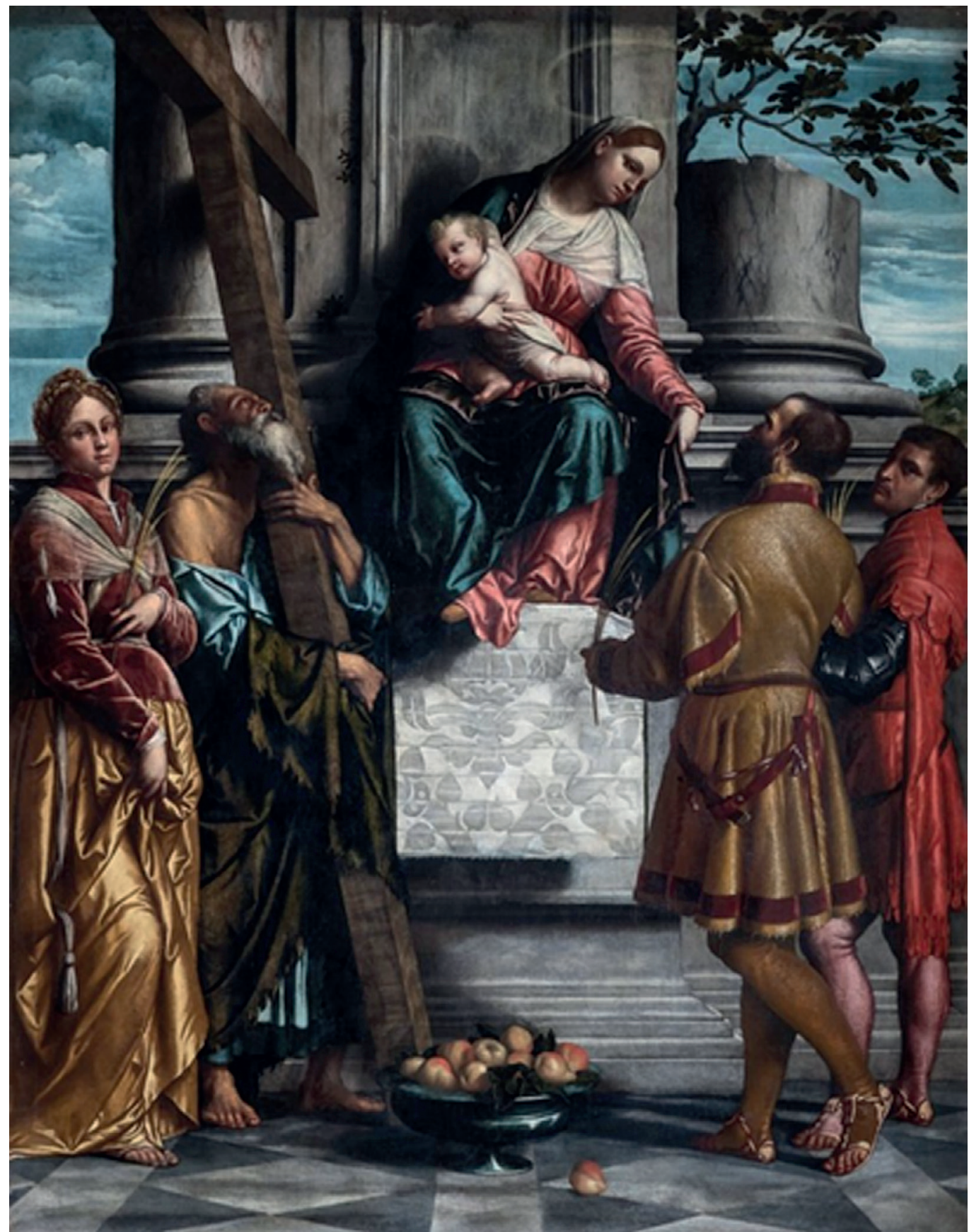

The conical projection is a rigorous central perspective at the main point positioned at the centre of the hanging. The geometric decoration of the flooring allows to the reconstruction of the geometry of the scene as well as to go back to the depth of the plinth even if covered, in part, by the prominent figures, with the Saints arranged in favour of the line of the proscenium, and the Madonna with the Child raised, as placed above a mechanè, above the other characters.

The Sacred Conversation, while following the Renaissance heritage, presents some mannerist elements, such as the fruit bowl with pears whose function is to enhance the perspective reading and direct attention towards the main point or, again, the breaking of the fourth wall through the looks facing outwards of the scene of Eusebia and Domneone; the rigid and formal pose of the characters within the theatrical grid, in fact, contrasts with the informal 
attitude of the two saints who address the observer directly. It is possible to recognize two types of relationships within the framework: a diegetic, which intervenes between Andrea, Domno and our Lady, and an extra-diegetic, which directly involves the viewer through the eyes of the other protagonists (fig. 3).

A realist ruse of the pictorial tradition of the Renaissance and aiming to involve the spectator in the history. Moretto thus rethinks the space, depending on the action of the actors adapting to their intentions the stage cage and "architecture almost hides behind the greatness of the figures" [Gombosi 1943, p. 47]. The saints are dynamic because of their actions, opposing the "Virgin and even more so the Child who shows more calm and adherence to rational space" [Gombosi 1943, p. 50]. In fact, Christ is drawn inclined on the left in a mirrored way to Mary, thus determining a $V$-shape whose lines of tension make the gaze converge on a second decentralized escape point, placed on the horizon line behind St. Domno [Boselli 1954].

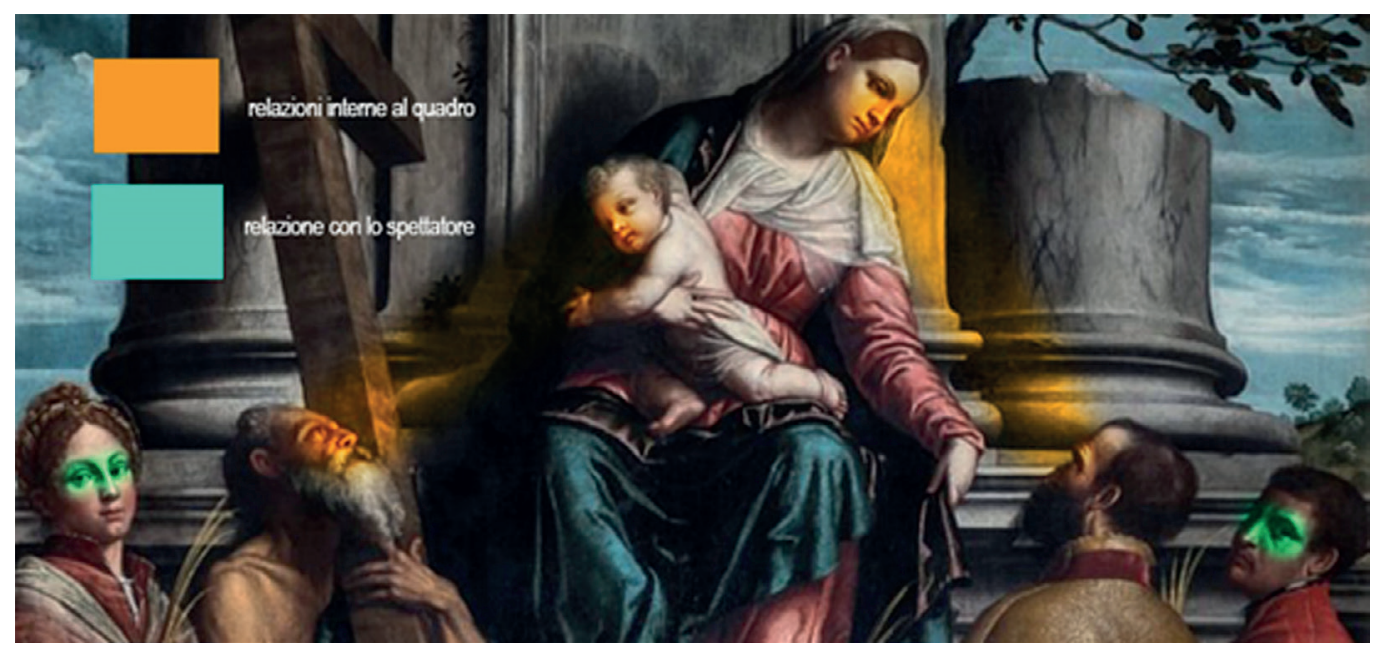

\section{The translation of the painting into a $3 \mathrm{~d}$ model}

The elaboration of the 3D model was the result of a process of translation of the pictorial form into numerical volumes all around, then resolved in high relief. A design, development organized on the needs and perceptibility of users (thanks to the collaboration with $\mathrm{UICl}$ of Bergamo) and preceded by the creation of the first physical prototypes that were improved following the tactile verification of users with visual disabilities. This allowed us to frame not only what was recognized by the visually impaired or blind persons, but also to what extent the content of the representation could be described through modelling and printing. The final objective has therefore strongly conditioned the construction of the model, not simply making it an exercise in a form aimed at an aesthetic evaluation, but a sculptural relief also appreciable to the eye.

The characters and objects depicted in the painting were broken up into isolated elements and returned in their three dimensions, then moved into the scenic space. The division into parts of the painting was made following coherent groups of actors and architectures, as well as including the attributes of holiness and smaller objects. The Pala has been disunited into ten subsets: the bottom with clouds and the hill, the plant; the plinth with columns and lesena, the flooring; the fruiting and, of course, the figures of the saints and our Madonna with Child (fig. 4).

Modelling has been done with the integrated use of multiple software, both 2D graphics (Adobe ${ }^{\circledR}$ Photoshop and Adobe ${ }^{\circledR}$ Illustrator) to discount silhouettes and complete them were hidden and/or incomplete, and modelling to make them virtual volumes (Autodesk $\circledast$ ) 


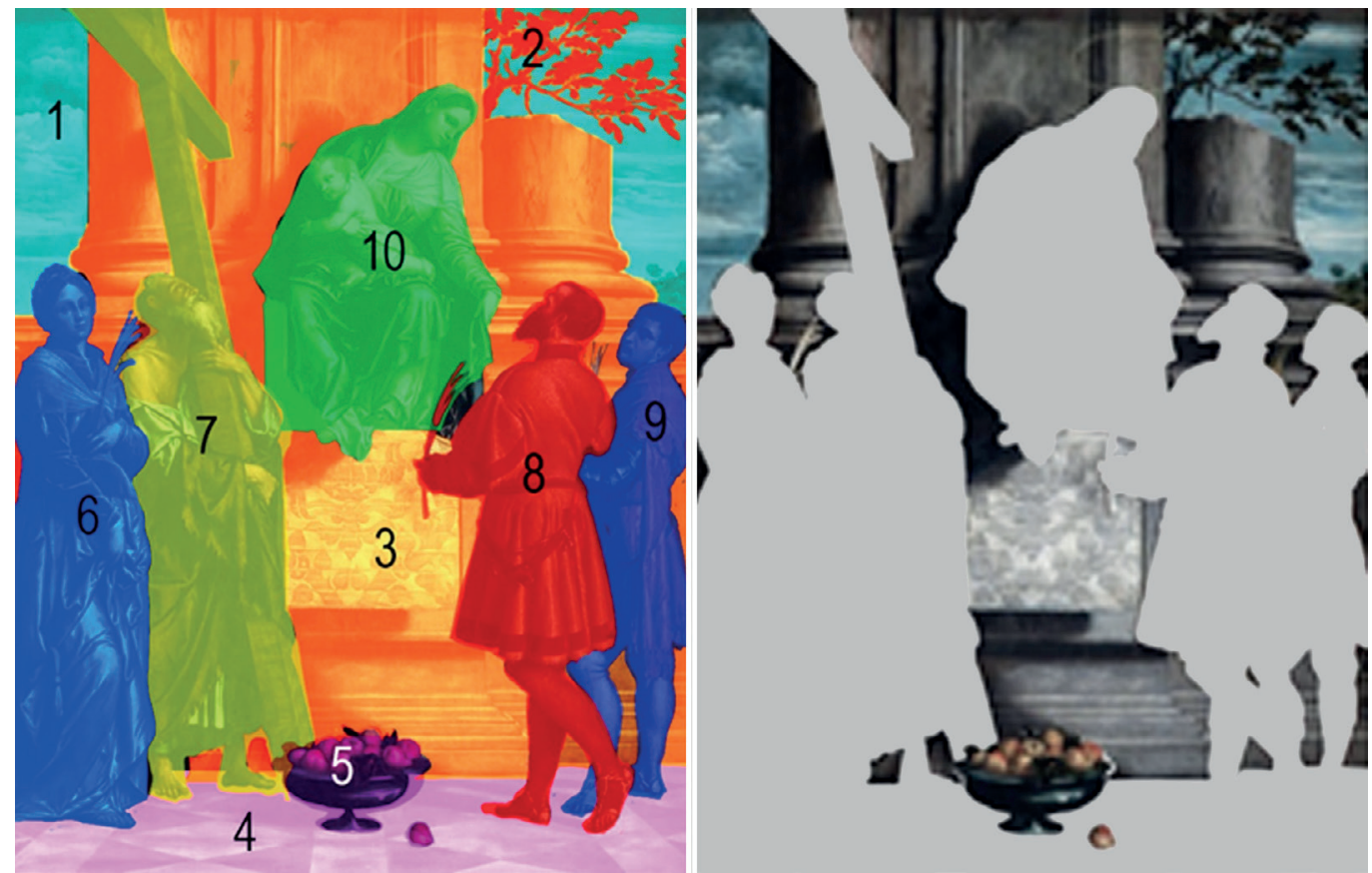

3D Studio Max, Pixologic $®$ Zbrush). The translation of the architectures was based on the rules of perspective, that of the characters followed a more 'artistic' practice to respect the body proportions and the return of facial expressions (fig. 5).

The digital cast of the background did not reproduce the clouds and the tree-lined hill due to the minute detail that would make furrows very dense to be understood with touch; the seabed has been replaced by a simple polished plain, leaving the sound integration with the

Fig. 5. The reconstruction of the architectural elements in Autodesk $\circledast$ 3D Studio Max and the modellina fruit bowl in Pixologic $®$ Zbrush.
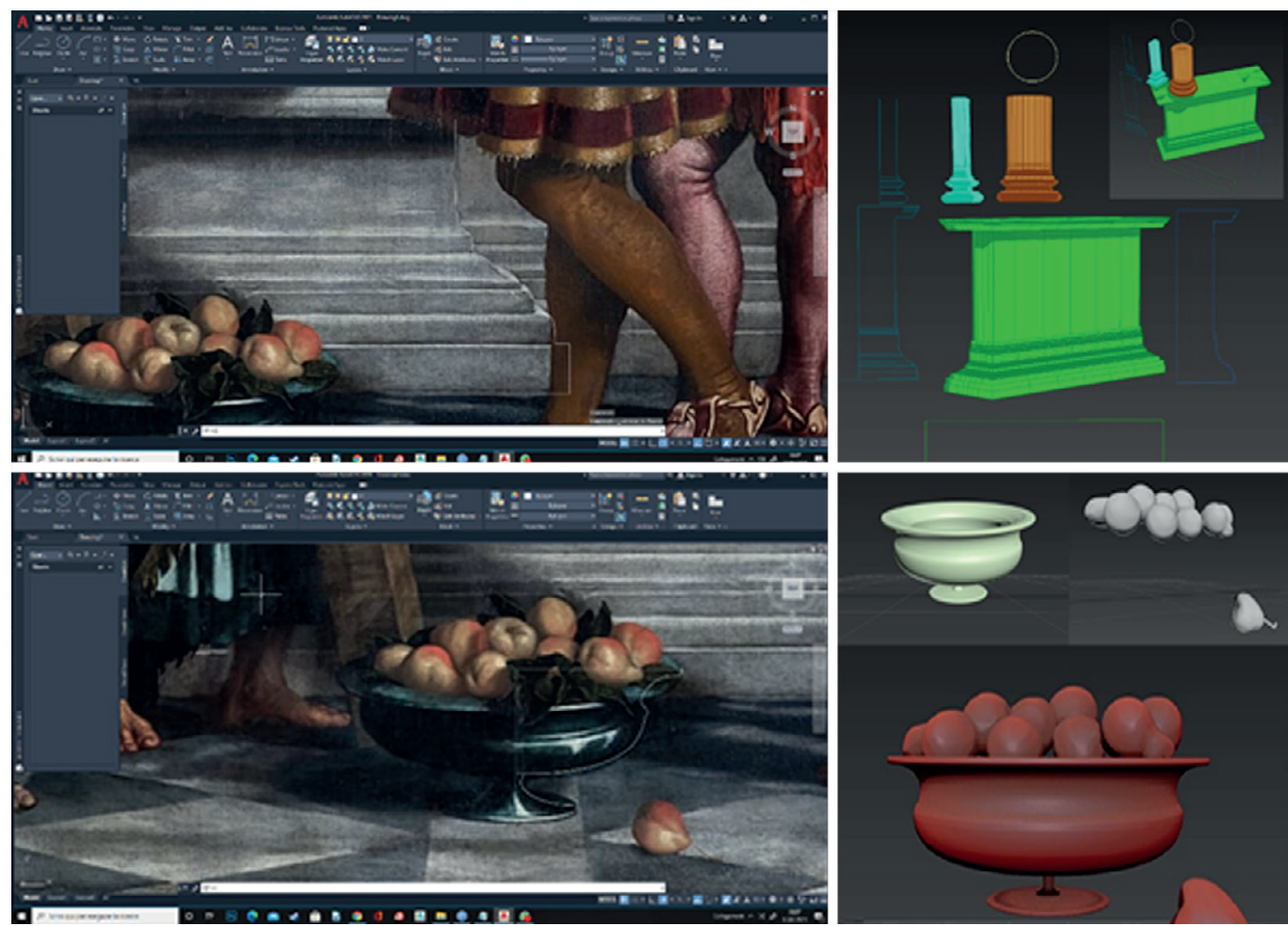


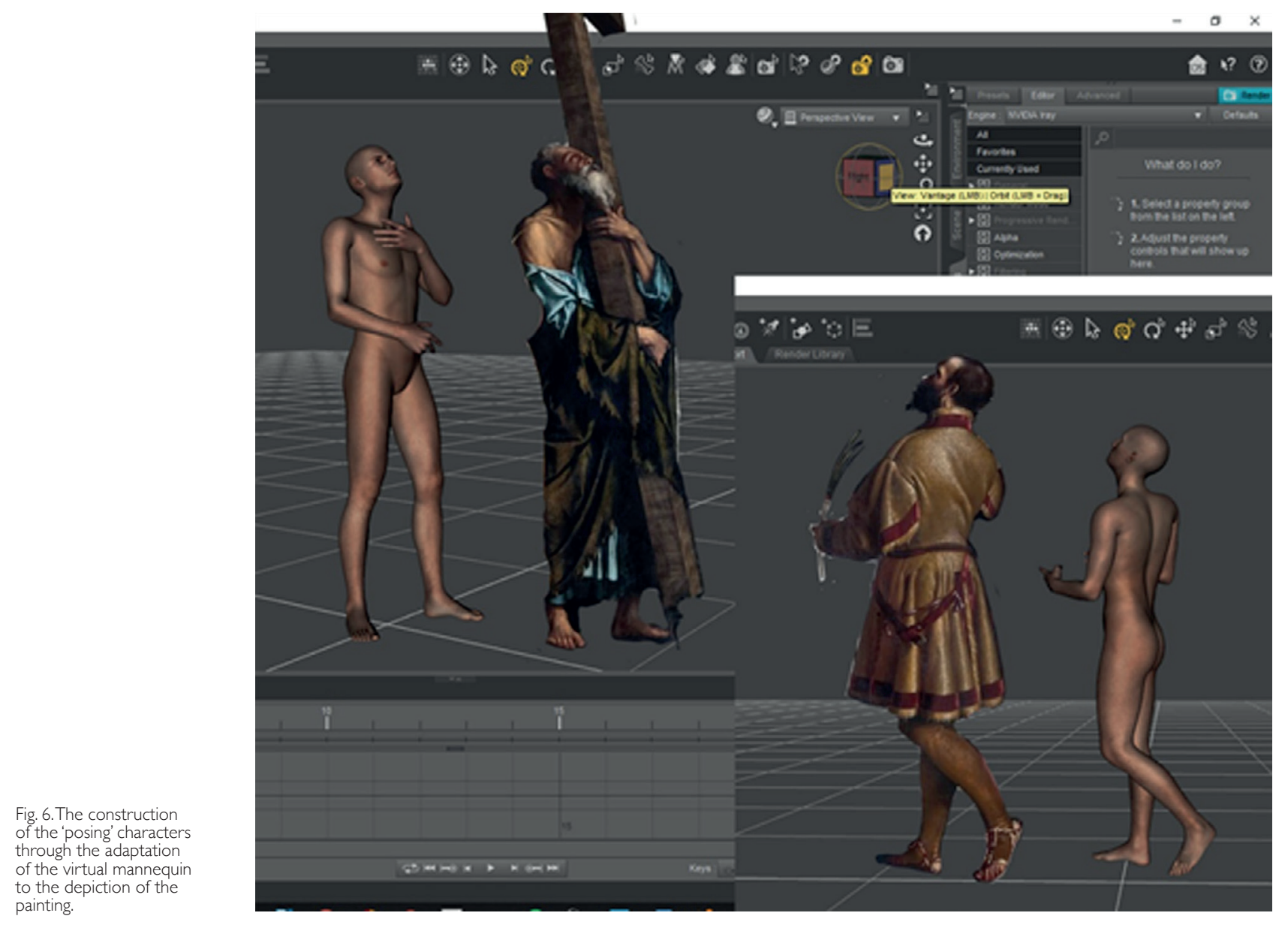

description deepening of the contents. The same choice was made in the flooring because the geometric design would have distracted attention from the prominent characters; the tests conducted with $\mathrm{UICl}$ have highlighted how the decorative motif, fundamental to the viewer to read the depth of the scene, is not able to communicate the sense of spatiality to visually impaired or blind people.

The modelling of the characters required a different approach because it was necessary to focus on their expressiveness, to communicate the hierarchy, social and emotional relationship in place between the interpreters. The comprehension of the interactions between the actors, through the recognition of looks and poses, was functional to the narration. This aspect is one of the prerogatives of visual representation, but it is transitory in tactile reading. For this reason, an attempt was made to use, in virtual design, a dimensional scale that could allow two or more subjects to be heard at the same time during the gesture of tactile reading.

This was achieved through a design process that, for each character, was divided into three different and sequential phases: the creation of the pose (with the placement of a virtual mannequin without physiognomy connotations), the characterization (through the expression of the face and dressing with clothes and accessories), the anthropomorphic deformation to accentuate the tactile perception of the most significant elements (fig. 6).

The motives of the characters were possible thanks to the Daz3D software $\AA$ Daz Studio because it offers a vast sample of virtual mannequins that you can attitude through the movement of the head, trunk and limbs in postures that simulate the human body. The dressing, however, took place with polygonal modelling in Autodesk $\circledast 3 D$ Studio Max and was completed in Pixologic $®$ Zbrush. A complex and, so to speak, craft practice which 
Fig. 7. The characterization of the characters with 3D modelling of facial expressions and dressing in clothes and accessories.

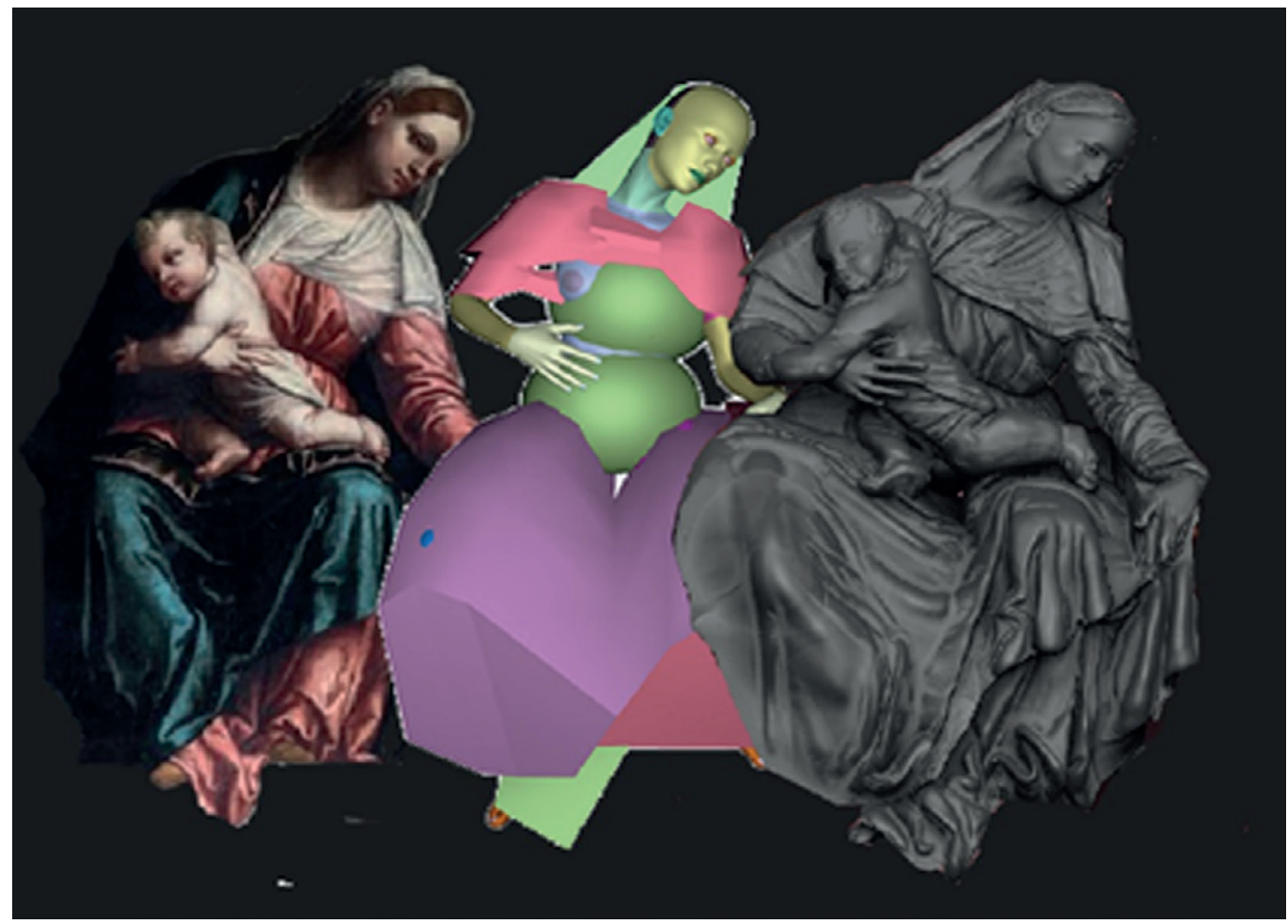

allowed a greater realism in the definition of drapes. To make the dressing consistent, therefore, with the pictorial representation, it was necessary to merge it with the dummy in such a way that, through free modelling, it could be adapted as a single object (fig. 7). A necessary choice because the realistic rendering of bodies expressed with folds, weaves and effects related to physics is not able to reflect the internal realism of a painting; physical dynamics cannot translate artistic dynamics, developed as language and therefore through a certain level of abstraction (fig. 8).

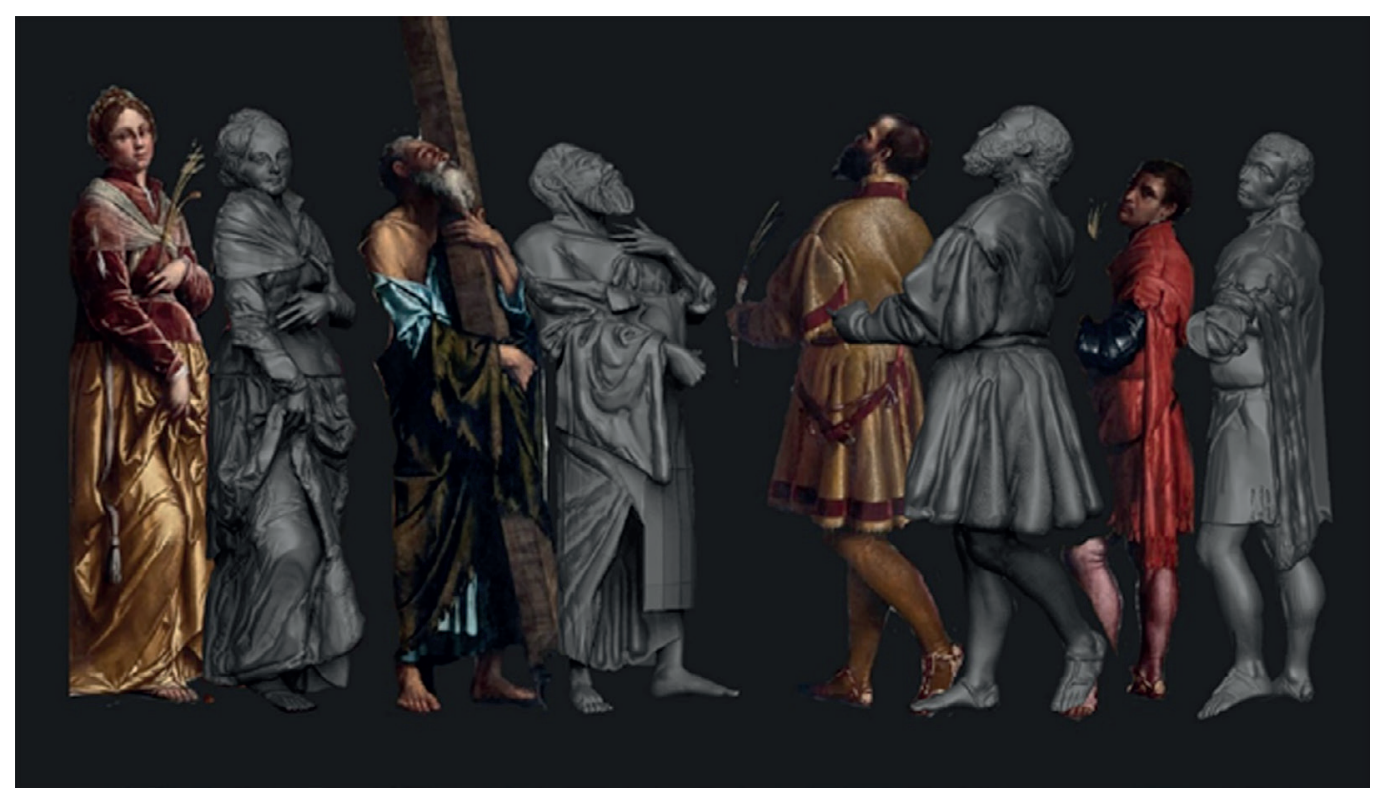




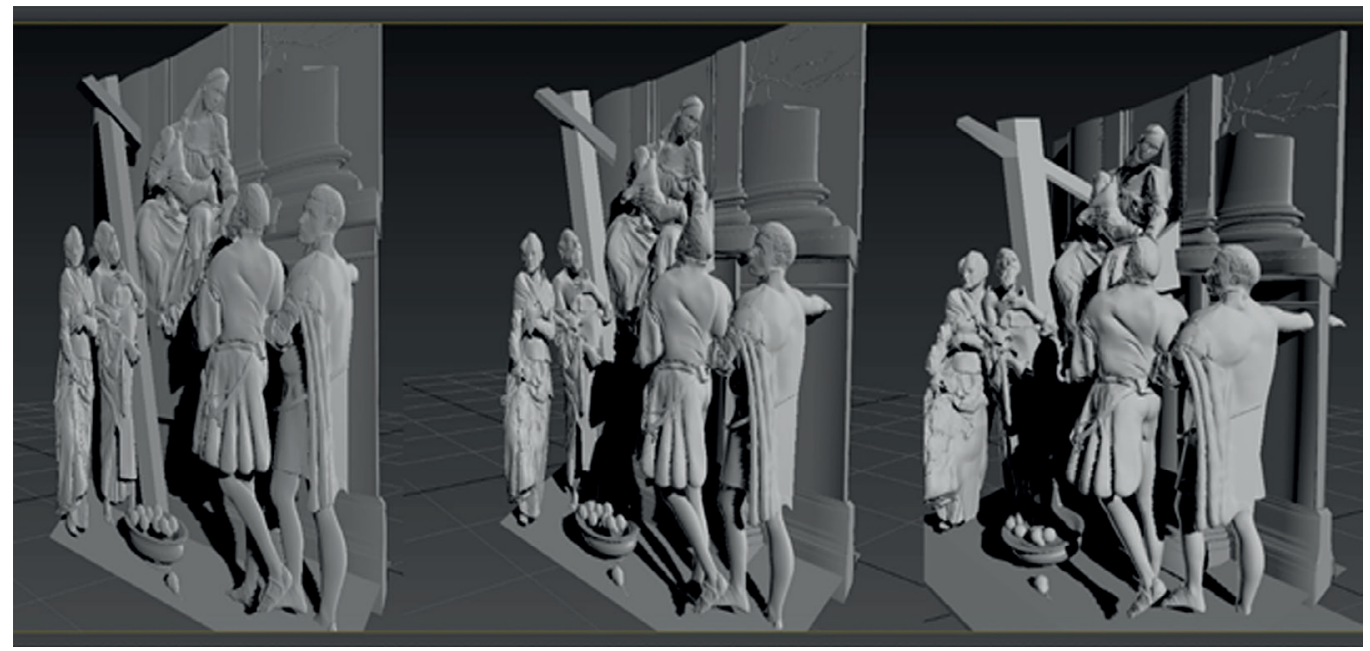

\section{D printing and virtual highrelief}

The physical translation of the painting required adapting the image to the dictates of sculptural art; a critical analysis in search of the right relationship between the true correspondence of the geometric-spatial structure of the representation, the obligatory stylization of the form (also due to the technical possibilities of three-dimensional printing), the needs of a conception of hypo-see and /or blind subjects [Riavis 2020].

The space cage has been imagined as the materialization of the perspective image, with the actors and objects positioned and spaced between them; a configuration difficult to read by those who bring a visual handicap because interrupting tactile continuity does not allow to guess the relationships between the various parts of the painting. On the other hand, the authors have abandoned the traditional path of extreme simplification of content in simple relief profiles, common to various museum experiences [Tiberti 2020], which would have caused the loss of the richness of the scene and rendered the research activity vain.

The artistic expression of the high relief appeared the most appropriate choice because it was able to preserve the characteristics of the relief design without sacrificing the richness of the details; a shortening of the depth and inclination of the floor and the scenes was experienced while keeping the overlapping figures detached and highlighting the division between the different draperies. A tactile recreation of perspective fiction that has allowed to reveal the illusion of distance, based on a system of perception linked with sight, declaring it to the touch as if space suffered an uneven reduction in scale and limited to the orthogonal direction only to the painting (fig. 9).

A solution that answered the question of respect for the meaning of the work of art that, despite the constraint of the elements of forced composition within a narrower grid, continued to express the originality of the scene and the idea of the interactions of the actors. An opportunity not granted with the simple embossed schematic design, able to allow visually handicapped people to mentally reconstruct relationships, and enjoy the volumes and contrasts of shadows and lights transposed in distances and depths (fig. I0).

\section{Conclusion}

The project was a pragmatic experiment in the materialization of the formal and significant components of a pictorial work; through the transcription in high relief, on the one hand, the expressive peculiarity connected with the use of colour and chiaroscuro has been maintained, on the other hand, the illusory construction of the perspective has been revealed and a reflection on the link between the image and the plastic yield has begun. The 
abandonment of colour because it is inscrutable to an audience of visually impaired and blind people, has led to the creation, not of a copy, but a singular and unique sculptural work, autonomous and independent of the original.

The translation carried out did not in fact use the same language of painting, but a totally different semiotic; the reason for fruition through which the model was developed differentiated it from the original, making it a complement that increases its artistic meaning and that can also be used by those who have the incredible gift of sight.

Fig. 10.The final model in a rendered image with ChaosGroup@ Vray produced within the Autodesk ${ }^{\circledR}$ 3D Studio Max modelling software.

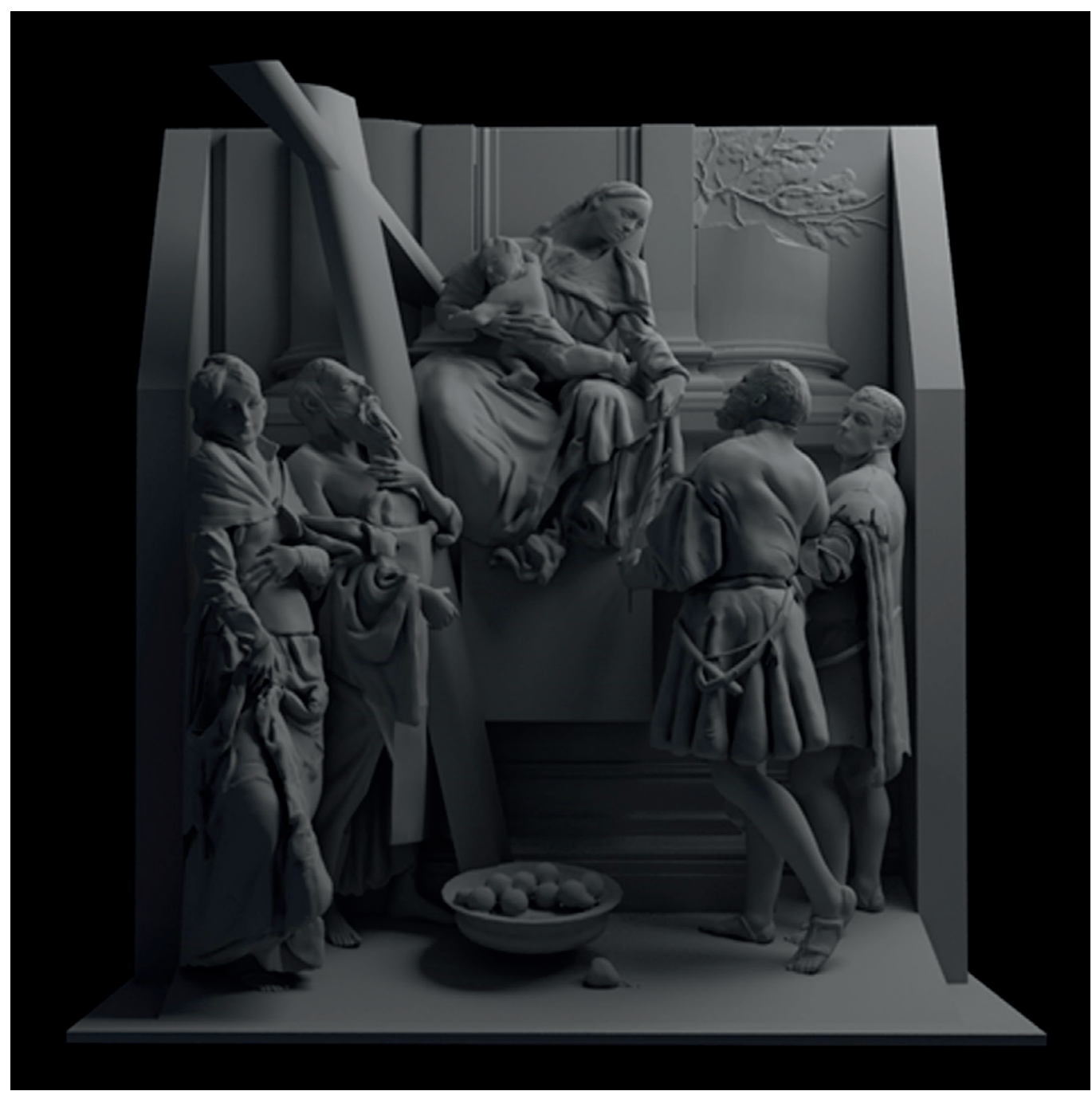

Credits

The research activity was conducted synergistically by authors who shared objectives, methods and results. The editorial responsibility is also shared: Alessio Cardaci (Introduction, first paragraph and conclusion), Francesco Sala (second, third and fourth paragraphs).

\section{References}

Ansaldi B. (2018). Perspective and the Blind: towards a communication of painted spaces to the visually impaired. In ICGG 2018 - Proceedings of the $18^{\text {th }}$ International Conference on Geometry and Graphics. Cham: Springer International, pp. 54I-552.

Bellini A. (2000). Toccare l'arte: l'educazione estetica di ipovedenti e non vedenti. Roma: Armando Editore.

Boselli C. (1954). II Moretto: I 498-I554. In Commentari dell'Ateneo di Brescia per l'anno 1954 (Supplemento). Pubblicazione commemorativa nel quarto centenario della morte del Moretto. Brescia:Tipografia Fratelli Geroldi. <https://www.ateneo.brescia. it/controlpanel/uploads/supplementi-ai-commentari/S-I954a\%20Boselli\%20Moretto.pdf> (accessed 202 I, May I0). 
Cardaci A. (2019). La Chiesa di Sant'Andrea in via Porta Dipinta a Bergamo: dallo studio critico degli antichi disegni al rilievo per la conoscenza della fabbrica. In $41^{\circ}$ convegno internazionale dei docenti delle discipline della rappresentazione. Congresso della unione italiana per il disegno. Roma: Gangemi Editore, pp. 509-5 I6.

Gombosi G. (1943). II Moretto da Brescia. Basilea: Holbein-Verlag.

Levi F. (20 I 3). L'accessibilità alla cultura per i disabili visivi: storia e orientamenti. Torino: Zamorani.

Poscolieri M. (2019). La percezione della pittura: oltre le barriere visive. In Baroni S. Bertini F. (a cura di). Tradurre la pittura: incisioni e quadri tattili (Giornata di studi, Roma, 3 dicembre 2019), pp. 299-317. Roma: Universitalia, .

Riavis V. (2020). La Chiesa di Sant'lgnazio a Gorizia tra architettura e pittura: analisi geometrica e restituzioni per la rappresentazione tattile. Trieste: EUT Edizioni Università di Trieste. <https://www.openstarts.units.it/handle/ I0077/3 I 055> (accessed 202 I, May I0),

Rizzi E. (200 I). Percezione e linguaggio: problemi critici. Firenze: Cadmo Editore.

Rodeschini M. C. (|98|). Note sulle due pale del Moretto a Bergamo. In AA.WV. Notizie da Palazzo Albani: rivista annuale di storia e teoria delle arti. (10-2). Urbino: Edizioni QuattroVenti.

Romeo K. et al. (2018). Simplification of Painting Images for Tactile Perception by Visually Impaired Persons. In: Miesenberger K., Kouroupetroglou G. (Eds.). Computers Helping People with Special Needs. ICCHP 2018. Lecture Notes in Computer Science, vol. 10897. Cham: Springer.

Tiberti V. (2020). Il museo sensoriale: l'accessibilità culturale e l'educazione artistica ed estetica per le persone con minorazione visiva nei musei del comune di Roma. Roma: Sapienza Università Editrice.

Uccelli P.A. ( 1874). Dei santi martiri Domno Domnione ed Eusebia venerati nella Chiesa prepositurale di Sant'Andrea in Bergamo: Commentario. Bergamo:Tipografia Pagnoncelli.

\section{Authors}

Alessio Cardaci, Università di Bergamo, falessio.cardaci@unibg.it

Francesco Sala, Università di Bergamo, f.sala22@studenti.unibg.it

To cite this chapter: Cardaci Alessio, Sala Francesco (2021). La Pala del Moretto della Chiesa di Sant'Andrea: una traduzione 3D per la fruizione di soggetti con disabilità visiva/The Pala del Moretto of the Church of Sant'Andrea: a 3D Translation for People with Visual Disabilities. In Arena A. Arena M., Mediati D., Raffa P. (a cura di). Connettere. Un disegno per annodare e tessere. Linguaggi Distanze Tecnologie. Atti del $42^{\circ}$ Convegno Internazionale dei Docenti delle Discipline della Rappresentazione/Connecting. Drawing for weaving relationship. Languages Distances Technologies. Proceedings of the 42th International Conference of Representation Disciplines Teachers. Milano: FrancoAngeli, pp. 215 I-2 172 